UNIVERSIDADE DE SÃO PAULO

FACULDADE DE ECONOMIA, ADMINSITRAÇÃO E CONTABILIDADE DE RIBEIRÃO PRETO

DEPARTAMENTO DE ECONOMIA

PROGRAMA DE PÓS GRADUAÇÃO EM ECONOMIA - ÁREA: ECONOMIA APLICADA

Gustavo Sung

The effects of the central bank intervention auctions on the foreign exchange futures market: evidence from Brazil

Supervisor: Alex Luiz Ferreira

Ribeirão Preto

2021 
Prof. Dr. Vahan Agopyan

Rector of University of São Paulo

Prof. Dr. André Lucirton Costa

Director of School of Economics, Business Administration and Accounting at Ribeirão Preto

Prof. Dr. Sérgio Kannebley Junior

Head of Economics Department

Prof. Dr. Luciano Nakabashi

Coordinator of Graduate Program in Economics - Area: Applied Economics 


\section{Gustavo Sung}

\section{The effects of the central bank intervention auctions on the foreign exchange futures market: evidence from Brazil}

Dissertation presented to Postgraduate Program in Economics - Area: Applied Economics in the

School of Economics, Business Administration and Accounting at Ribeirão Preto of University of São Paulo to obtain a Master's degree.

Supervisor: Alex Luiz Ferreira

Versão Corrigida. A original encontra-se disponível na FEA-RP/USP.

Ribeirão Preto 
For the purposes of study and research, I authorize the reproduction and total or partial disclosure of this work, by any conventional or electronic means, as long as the source is mentioned.

Part of this dissertation belongs to a paper written in co-authorship with Dr. Alex Luiz Ferreira preliminary entitled "A day in the futures: investigating the impact of central bank interventions in the FX market in Brazil."

\footnotetext{
Sung, Gustavo

The effects of the central bank intervention auctions on the foreign exchange futures market: evidence from Brazil. Ribeirão Preto, 2021

78p. : il. ; $30 \mathrm{~cm}$

Dissertação de Mestrado, apresentada à Faculdade de Economia, Administração e Contabilidade de Ribeirão Preto/USP. Área: Economia Aplicada .

Orientador - Prof. Dr. Alex Luiz Ferreira
}

1. Mercado de câmbio brasileiro. 2. Leilão e intervenção do Banco Central. 3. Microestrutura de mercado. I. Orientador: Prof. Dr. Alex Luiz Ferreira. II. Universidade De São Paulo - Campus Ribeirão Preto. III. Faculdade de Economia, Administração e Contabilidade de Ribeirão Preto. IV. Os efeitos dos leilões de intervenção do Banco Central no mercado futuro de câmbio: Evidências do Brasil. 


\section{Acknowledgements}

Firstly, I would like to thank professor Alex Ferreira for his guidance and enthusiasm with this dissertation.

In this Covid-19 pandemic time, I had the privilege and the opportunity to continue my education, and hence, I am very grateful for my family's support.

Lastly, I would also thank my friends and masters' colleagues that help me in this journey.

This study was financed in part by the Coordenação de Aperfeiçoamento de Pessoal de Nível Superior - Brasil (CAPES) - Finance Code 001. 


\begin{abstract}
Sung, G. The effects of the central bank intervention auctions on the foreign exchange futures market: evidence from Brazil. School of Economics, Business Administration and Accounting at Ribeirão Preto, University of São Paulo, Ribeirão Preto, 2021.

This research studied market participants' behavior to the Central Bank of Brazil (CBB) FX intervention auction. Our objective was to understand how market participants reacted to these macroeconomic events, incorporated new information, and transmitted it to the prices. Based on high-frequency data, it was examined and described a specific trading day of the Brazilian FX futures market, November $26^{\text {th }}$, 2019. This strategy allowed us to identify the exact moment the new information arrived and how the market participants reacted. Empirically, we analyzed how those intervention auctions affected the market liquidity and the contribution of bid and ask quotes to price discovery. We used four liquidity indexes and the information share (IS) and the component share (CS) price discovery metrics. The liquidity results showed that the most illiquidity periods occurred at the CBB FX intervention auction periods, mainly the unexpected ones. As for the price discovery, the results indicated that the contribution of the bid (buy-side) and ask (sell-side) quotes to price discovery was asymmetric on that day. With more net buys in the market, the sell-side contributed more to price discovery than the buy-side. In addition to that, the contribution of bid quote and ask quote to price discovery in the Brazilian futures markets varied along the day. The CBB FX selling intervention auctions and, consequently, the negative order flow impacted those changes.
\end{abstract}

Keywords: Foreign Exchange Markets; Central Bank of Brazil FX intervention auctions; Market Microstructure.

JEL Code: F31; G14; G15. 


\section{Resumo}

Sung, G. Os efeitos dos leilões de intervenção do banco central no mercado futuro de câmbio: evidências do Brasil. Faculdade de Economia, Administração e Contabilidade de Ribeirão Preto, Universidade de São Paulo, Ribeirão Preto, 2021.

Esta pesquisa tem como objetivo estudar o comportamento dos participantes do mercado diante dos leilões de intervenção cambial do Banco Central do Brasil (CBB). Procuramos entender como os participantes do mercado reagiram a esses eventos macroeconômicos, incorporaram novas informações e as transmitiram para os preços. Utilizando dados de alta frequência do mercado de câmbio futuro brasileiro, investigamos um dia de pregão 26 de novembro, 2019. Essa estratégia nos permitiu identificar o momento exato em que as novas informações chegaram e como o mercado reagiu. Empiricamente, analisamos como esses leilões de intervenção afetaram a liquidez do mercado e a descoberta de preços entre vendedores (ask quote) e compradores (bid quote). Usamos quatro índices de liquidez e para a descoberta de preço, as métricas Information Share (IS) e do Component Share (CS). Os resultados de liquidez mostraram que os períodos de maior iliquidez ocorram durante os leilões de intervenção, principalmente nos não programados. Quanto à descoberta de preços, os resultados indicaram que a contribuição entre compradores e vendedores foi assimétrica. Com maior pressão de compra no mercado, o lado da venda contribuiu mais para a descoberta do preço do que o lado da compra. Além disso, essa contribuição para formação do preço variou ao longo do dia. A presença de leilões de venda do CBB e, consequentemente o fluxo de ordem negativo, impactaram os resultados.

Palavras-chaves: Mercado de câmbio brasileiro; Leilão e intervenção do Banco Central; Microestrutura de mercado.

JEL Code: F31; G14; G15. 


\section{Contents}

1 Introduction 1

2 Literature Review $\quad 4$

2.1 Price Discovery and Liquidity . . . . . . . . . . . . . . . . . 4

2.2 Central Bank's Interventions $\ldots \ldots \ldots \ldots$

$\begin{array}{llr}3 & \text { Methodology } & 8\end{array}$

3.1 Liquidity Indexes . . . . . . . . . . . . . . . . . . . . 8

3.2 Price Discovery . . . . . . . . . . . . . . . . . . . . . . . 10

4 Data 13

4.1 November $26^{\text {th }}, 2019 \ldots \ldots \ldots \ldots \ldots \ldots \ldots$

4.1 .1 Duration, Volume, and Order flow . . . . . . . . . . . . . 24

4.1 .2 Market Participants . . . . . . . . . . . . . . . 28

4.1 .3 Limit Order Book . . . . . . . . . . . . . . . . . . 30

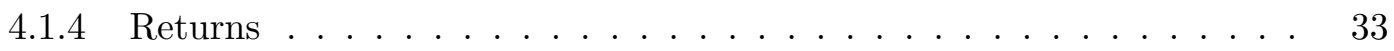

5 Liquidity Results $\quad 35$

5.1 Relative Spread . . . . . . . . . . . . . . . . . . . . . . 35

5.2 Illiquidity Indexes $\ldots \ldots \ldots \ldots \ldots \ldots$

5.3 Price Impact and Return Reversal _ . . . . . . . . . . . . . . . . . . 40

6 Price Discovery Results $\quad 42$

$\begin{array}{lll}7 & \text { Conclusion } & 46\end{array}$ 


\section{List of Figures}

1 PTAX: January 3,2000 to November 26, $2019 \ldots \ldots \ldots \ldots$

2 Trading price per second . . . . . . . . . . . . . . . . 17

$3 \quad$ Structure of the trading tunnels . . . . . . . . . . . . . . . . . . . . . 22

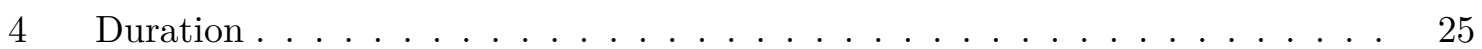

$5 \quad$ Volume $(\mathrm{USD})$ per second $\ldots \ldots \ldots \ldots \ldots$

$6 \quad$ Volume $(\mathrm{USD})$ per hour $\ldots \ldots \ldots \ldots \ldots \ldots$

$7 \quad$ Order flow (USD billion) per second $\ldots \ldots \ldots \ldots \ldots \ldots$

8 Accum. Order flow per second (Green) x DOLZ19 prices per second (Red) . . 28

$9 \quad$ Best bid and Ask quotes per second . . . . . . . . . . . . . . . 32

10 Mid-Quote per second . . . . . . . . . . . . . . . . . . . 32

11 Spread per second $\ldots \ldots \ldots \ldots \ldots \ldots \ldots \ldots \ldots$

12 Return per second . . . . . . . . . . . . . . . . . . 34

13 Squared Return per second . . . . . . . . . . . . . . . . . 35

14 Relative Spread per second . . . . . . . . . . . . . . . . . . . 36

15 Illiquid Index: One-minute interval . . . . . . . . . . . . . . . . . . 37

16 Illiquid Index: Volume . . . . . . . . . . . . . . . . . . . . . . . . 38 


\section{List of Tables}

$1 \quad$ Main News . . . . . . . . . . . . . . . . . . . 18

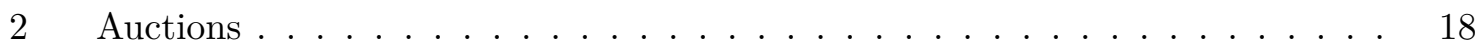

$3 \quad$ Descriptive statistics . . . . . . . . . . . . . . . . . . . . . 19

$4 \quad$ Price Variation I . . . . . . . . . . . . . . . . . . . . . . . . . 24

$5 \quad$ Price Variation II . . . . . . . . . . . . . . . . . . . . . . . . 24

$6 \quad$ Buy-sell Volume Shares . . . . . . . . . . . . . . . . . . . . . . . . 30

$7 \quad$ FX interbank Dealers-14 . . . . . . . . . . . . . . . . . . . 30

$8 \quad$ Limit Order Book . . . . . . . . . . . . . . . . . . . . . . . 31

9 Return and Squared Returns _. . . . . . . . . . . . . . . . 34

10 Liquidity Indexes $\ldots \ldots \ldots \ldots$

11 Price Impact and Return Reversal _ . . . . . . . . . . . . . . . . . . . . 40

12 Price Impact and Return Reversal II . . . . . . . . . . . . . . . . . . . . . . . 41

13 Johansen co-integration test . . . . . . . . . . . . . . . . . . . 43

14 VECM Results . . . . . . . . . . . . . . . . . . . . . . 44

15 Price Discovery . . . . . . . . . . . . . . . . . . . 46 


\section{Introduction}

Several studies are contributing to the analysis of price discovery in multiple venues (Hasbrouck, 1995, 2003; Baillie et al., 2002; de Boyrie et al., 2012; Yan and Zivot, 2010); and, for the case of Brazil (Ventura and Garcia, 2012; Garcia et al., 2015). Those studies allowed us to understand which venue firstly incorporates new information relative to the others, reflecting their leadership in price discovery. Besides, another part of the literature studies price discovery in the same market (Engle and Patton, 2004; Escribano and Pascual, 2006; Pascual and Pascual-Fuster, 2014; Chen and Gau, 2014, 2015). These papers explore whether and how possible asymmetric information by the buyers and sellers may affect the price discovery. They analyze the contribution of the bid (buy-side) and ask (sell-side) quotes to the efficient price.

Some kinds of asymmetry may result from trade-related shocks, differences in trading costs, or differing quote responses from both sellers and buyers to new information. Chen and Gau (2014) reported that in the Euro-Dollar spot market, the bid quotes prevail over the ask quote in price discovery. Escribano and Pascual (2006) found asymmetric adjustments on the bid and ask prices to trade-related shocks and buyer and seller-initiated trades impacts. Chen and Gau (2015), demonstrated that Japanese official interventions on the USD-JPY market affected the contribution of bid and ask quotes to price discovery.

In conjunction with the price discovery literature, market liquidity studies have also been developed. According to Hasbrouck and Levich (2019), although the price discovery focus on measuring the source of information and its incorporation into prices and the liquidity study investigates the trading costs, both concepts are economically related. The authors argued that the costs of price discovery, such as asymmetric information, are expected to be passed through as trading costs. From this perspective, they investigated the activity and the liquidity in the foreign exchange market.

The asymmetry in the Brazilian foreign exchange market may result from the institutional framework and their market concentration. The Brazilian FX market is divided into the spot market (primary and interbank market) and the derivatives market, and according to CBB (2019), ten banks represented $62 \%$ of total negotiated on the FX interbank market in 2018. Bastos and da Silva Fontes (2014) showed that between 2006 and 2007, the banks had $43 \%$ of the participation on future dollar contracts, the domestic institutional investors $29 \%$, and the foreign institutional investors 25\%. Garcia and Urban (2004) affirmed that 115 banks 
were authorized to negotiate in the FX spot market, but only 75 of them operated in 2003. In the same year, 20 banks concentrated $80 \%$ of the operations in the FX interbank market.

Another institutional feature that may contribute to information asymmetry on the Brazilian FX market is the Dealers-14. Dealers-14 are large banks and brokers, accredited by the $\mathrm{CBB}$, to quote, whenever requested, purchase and sale rates for foreign currencies, to participate in foreign exchange intervention auctions promoted by the $\mathrm{CBB}$, provide liquidity to the foreign exchange market, and participate in conference calls with the Brazilian monetary authorities ${ }^{1}$. Then, given their weights in the currency market and the link with the Central Bank of Brazil, they probably have more information about the market and the intervention process than other participants.

Within this framework, this research empirically studies the effects of CBB FX intervention auctions on the market liquidity and the contribution of bid and ask quotes to price discovery in the Brazilian FX futures market.

Based on high-frequency data, our study examines a specific trading day of the Brazilian foreign exchange futures market, as well as Goodhart et al. (1996), who analyzed tick-by-tick mark/dollar operations on Reuters electronic trading system on June 16, 1993.

This strategy allows us to identify the exact moment the new information arrived and how the market participants reacted. In our case, the understanding of market participants' behavior to a CBB FX auction in the Brazilian FX market and the impact on liquidity and price formation.

This research aims to contribute to the Brazilian financial microstructure literature. While it is well established that the price discovery mechanism on the Brazilian foreign exchange market originates in the futures market relative to the spot market (Ventura and Garcia, 2012; Garcia et al., 2015), to the best of our knowledge, there are no studies on the contribution of bid and ask quotes to price discovery in the Brazilian FX futures market within CBB FX intervention scope. In addition, it contributes to FX liquidity studies.

A detailed description of the trading day - time, prices, quantity, and market participants - gives an interesting perspective about the players' reaction to new information. Although the CBB has more knowledge over the interventions, this intraday study opens questions about information transmission.

There are several papers on CBB FX interventions, but they focused on the impact of the $\mathrm{CBB}$ interventions on the exchange rate levels, on the returns, and on the volatility

\footnotetext{
${ }^{1}$ Central Bank of Brazil norm no. 3.601 from March 31, 2013.
} 
(de Oliveira and Plaga, 2011; Nakashima, 2012; Kohlscheen and Andrade, 2013; Janot and Macedo, 2016).

Our investigation relied on November $26^{\text {th }}, 2019$, given a large number of CBB FX intervention auctions and the attractive foreign exchange rates dynamic. There were seven foreign exchange auctions, programmed and non-programmed ones. One of them halted the futures dollar contract trading for approximately 5 minutes.

We concentrated on the DOLZ19 FX futures market contract, one of the most liquidity contracts. The data comprises the tick-by-tick trading prices and bid-ask quotes, with their respective contract quantities, buy-sell aggressor signal, and financial and nonfinancial institutional code numbers.

From this perspective, this study relies on the illiquidity indexes from Hasbrouck and Levich (2019) and Mancini et al. (2013), and to analyze the contribution of bid and ask quotes to price discovery, this research uses the "Information share" (IS) from Hasbrouck (1995) and the "Component share" (CS) from Booth et al. (1999), Chu et al. (1999), and Harris et al. (2002).

The results showed that the most illiquidity periods occurred at the CBB FX intervention auction periods, mainly in the unexpected ones. In those periods, it is possible that market participants were incorporating the new information, and they were passing it into prices to cover potential losses.

As for price discovery results, the contribution of bid and ask quotes to price discovery was asymmetric in the Brazilian FX futures market. On that day, with accumulated net buys in the market, the ask quotes (sell-side) contributed more to price discovery than the bid quotes (buy-side), following the literature on the subject. However, the contribution of bid quote (buy-side) and ask quote (buy-side) varied during the day. A factor that impacted those changes was CBB FX auctions.

These results represent a brief portrait of the Brazilian FX market and do not illustrate the market as a whole. However, this approach allows an exciting analysis of the intervention's impacts on the market and could open many questions about them.

The rest of this study is organized as follows. Section 2 presents the literature review. Section 3 describes the price discovery metrics and the liquidity indexes, followed in Section 4 by a detailed data description and the main events on November $26^{\text {th }}, 2019$. Section 5 relates the liquidity results, Section 6 price discovery results, and Section 7 concludes. 


\section{Literature Review}

\subsection{Price Discovery and Liquidity}

The symmetric contribution of bid and ask quotes to price discovery is based on the hypothesis that the mid-quote, the midpoint between bid and ask quotes, represents the unbiased estimator of the non-observable efficient price. If this hypothesis is confirmed, then the bid and ask prices are equally informative to the true value of an asset (Pascual and Pascual-Fuster, 2014).

As described by Escribano and Pascual (2006), some authors model the transitory components of ask and bid prices as constant and equal-sized (Roll, 1984; Madhavan et al., 1997; Huang and Stoll, 1997). Others assume the same stochastic process to bid and ask quotes (Glosten and Harris, 1988; Lin et al., 1995; Hasbrouck, 1999). Escribano and Pascual (2006) and Pascual and Pascual-Fuster (2014) argue that if the contribution hypothesis is confirmed, a trade-related shock would affect bid and ask quotes simultaneously and in the same proportion (Glosten and Milgrom, 1985; Stoll, 1989).

However, a series of studies suggests that this hypothesis is not validated, and the bid and ask contribution to price discovery is asymmetric (Jang and Venkatesh, 1991; Engle and Patton, 2004; Escribano and Pascual, 2006; Laurini et al., 2008; Pascual and Pascual-Fuster, 2014; Chen and Gau, 2014, 2015).

The studies on the asymmetric contribution of bid and ask to price discovery relies on Amihud and Mendelson (1980) spread decomposition. The spread can be divided into operating costs, inventory costs, and adverse selection costs. Operating costs, such as administrative or order processes, are considered fixed and equal to buyers and sellers. Inventory costs occur when dealers or market makers, holding their position, bear the risk of losses to price movements. And, adverse selection costs arise due to asymmetric information.

Studies related to bid-ask asymmetric contributions focus on the inventory costs and the adverse selection costs. It is worth mentioning that, according to Pascual and PascualFuster (2014), Rime (2003), and Chen and Gau (2014), the inventory costs of the spread can be negligible in the pure order-driver market, which is the case of our study, because limit-order traders could avoid unnecessary inventory positions.

Naranjo and Nimalendran (2000) developed a theoretical model and provided empirical evidence of adverse selection costs due to U.S. and German official foreign exchange interventions. Considering DM-USD daily spot and 3-month forward foreign exchange from 
January 1976 to December 1994, the authors demonstrated that the bid-ask spreads are positively related to the variance of unexpected intervention, and the bid-ask spread levels increased with the government interventions.

Engle and Patton (2004) analyzed 100 NYSE stock price dynamics with an errorcorrection model and found asymmetries in the contribution of bid and ask to the efficient price. They argued that ask quotes were more impacted by the buys than sell trades, while the bid quotes by the sales than buys trades. Escribano and Pascual (2006) also presented evidence against several symmetry assumptions. The authors examined the NYSE-listed stocks and the Spanish Stock Exchange. They found asymmetric adjustments of ask and bid prices to trade-related shocks and argued that, in general, buys reflect more information than sales.

Likewise, Pascual and Pascual-Fuster (2014) also found asymmetries in the contribution of bid and ask quotes to price discovery and argued that this phenomenon was not driven by noise, but in fact, was due to the presence of substantial short-term stock-specific order imbalances. On days with excessive buyer-initiated trading, ask quotes are more influential in shaping the efficient price. In contrast, on days with excessive seller-initiated trading, bid quotes have more influence on price discovery.

Chen and Gau (2014) studied the price discovery in the Euro-Dollar spot market and found that the bid quotes contribute more to the price discovery, with more dominance on Monday and less so on Friday. They argued that these bid and ask asymmetries to trade-related information evolve with the daily return, the volatility, daily order flow, the interactive term between spread and order flow, skewness, and kurtosis in the distribution of efficient exchange rate changes.

Chen and Gau (2015) studied the asymmetric quotes contribution related to Central Bank interventions in the foreign exchange market. They analyzed the effects of Japanese interventions on the price discovery process in the USD-JPY market. With IS and CS metrics, they demonstrated that bid prices usually respond to information more quickly than ask prices. However, on days that Japanese monetary authorities intervened buying dollars, the ask quote contributions to the efficient price relative to bid quote increased. When the Japanese authority buys USD and sells JPY, the USD sellers update their ask prices more quickly to the new information, and hence, the informational efficiency of ask quotes increases.

Besides the price discovery literature, Hasbrouck and Levich (2019) argued that those studies had developed jointly with the market liquidity literature, and these two concepts 
are economically connected. The liquidity literature provides a framework for understanding market activity and how market participants incorporate new information and transmit it into the prices.

The authors investigated the activity and the liquidity in the FX market using CLS bank data. They used three FX order impact measures, a standard Amihud illiquidity ratio using fixed time intervals, an illiquidity ratio using intervals specified in a trading volume, and an impact coefficient estimated using bulk-volume classification. They analyzed thirteen currency pairs and observed a liquidity improvement between 2010-2013 and a decline between 2013-2016. Moreover, the authors found that the most traded currency pairs presented the smallest bid-ask spreads and the highest liquidity.

Mancini et al. (2013) introduced a systematic study of liquidity in the foreign exchange market. The authors utilized liquidity measures such as price impact, return reversal, trading cost, and price dispersion. From January 2007 to December 2009, and contemplating nine currency pairs from Electronic Broking System (EBS) data, they identified a significant variation in the liquidity, strong commonality across currencies, and substantial illiquidity costs.

Evans and Lyons (2002) developed an optimizing model and assessed whether macroeconomic news had an impact on market liquidity. The authors showed that macroeconomic news reduced the market liquidity in the $\mathrm{DM} / \$$ market, mainly after those announcements. The lower the liquidity, the greater the trade impact on prices. They argued that the pace of public information flow impacts the time-varying liquidity in the FX market, and the liquidity did not appear to depend on trading volume or return volatility.

\subsection{Central Bank's Interventions}

The second important piece of literature of this research is Central Bank's FX interventions and their effects on the foreign exchange rates. Although those methodologies are not linked to this study, their results support our analyzes. All the following studies argue that the Central Banks interventions affect, to some degree, the foreign exchange market.

Payne and Vitale (2003) used high-frequency data from 1986 to 1995 to analyze the effects of sterilized intervention operations by the Swiss National Bank (SNB) on the US Dollar (USD)/SWISS Franc (CHF) spot market. Based on the event study, they analyzed the SNB intervention's effects on the exchange rate returns. The authors showed that those interventions had a persistent effect, and they were more effective when coordinated with 
other countries.

Pasquariello (2007) also analyzed SNB interventions, contemplating an intraday CHF/USD spot exchange rate from 1986 to 1999. The author found that SNB interventions affected different measures of exchange rate behavior, market liquidity, short and long-run trading intensity, and ex-post volatility.

Dominguez (2003) analyzed the effects of the USA, Japan, and Germany Central (G3) Bank interventions in the USD-DEM and USD-JPY markets between 1987 and 1995. Using 5-minutes high-frequency intraday spot market data and Reuters' reports, the author found that some traders knew about the Fed's intervention at least 1 hour before released to the public. Moreover, the interventions were more effective in periods of high-volume trading and when they were coordinated with other central banks.

Dominguez (2006), updated the data to 1989 through 1995 and added to the estimation event study model a daily volatility seasonal component. The author showed that interventions impacted the intraday and daily exchange rate volatility, mainly on the G3 coordinated operations. But, there was little evidence of the interventions' effects on longer-term volatility.

For the Brazilian market, Nakashima (2012) used the event study methodology to verify the existence of abnormal returns (BRL/USD futures contracts) nearly to the CBB FX interventions auctions in the spot market. Considering high-frequency data between May 2009 and September 2010, they found statistically positive abnormal returns minutes after the auction opening and negative values following the auction closing.

The author investigated auctions that had 10 minutes bid periods and argued that the increase in the order flow minutes after the auction opening, which impacted the returns, is a signal of asymmetry increase.

Despite the intersection with our thesis, our research investigates the impact of the $\mathrm{CBB}$ intervention auctions on market liquidity and price discovery. Also, in contrast to Nakashima (2012), we calculated the asymmetry information between buyers and sellers in the FX futures market.

Besides, our database is richer. Our data comprises the aggressor buy-sell signals, market participants' trading codes - which is possible to identify the market players' behavior - bid and ask quotes and their respective volumes. Also, our research examines auctions in the Brazilian futures market that halted the trading process for a short period.

Kohlscheen and Andrade (2013) contemplated a high-frequency data and event study 
approach to analyze the effects of FX swap auctions on the exchange rate. Using 10-minute intervals, they showed that the maximum impact on exchange rates occurred 60 to 70 minutes after the CBB announcement and argued that those impacts are associated with the auction's result release.

Janot and Macedo (2016) analyzed the effects of CBB interventions on the intraday return and volatility between October 2011 and March 2015. Based on 5 minutes BRL/USD high-frequency future contract prices, they showed that non-programmed interventions had more and persistent impact on the foreign exchange market than the programmed ones. Also, the intervention size influences foreign exchange rates. Their results did not present any anticipation by market participants on the non-programmed FX interventions and no evidence that $\mathrm{CBB}$ operations contributed to reducing exchange rate volatility in the short run.

Santos (2021) studied the impact of pre-announced and unexpected CBB FX interventions on the exchange rate. Based on high-frequency data from October 2011 to December 2013 - aggregated by 15-minute intervals - the author found that the unexpected interventions are more effective than the pre-announced ones, and those effects persist on the intervention day and the following day.

All these studies support our hypothesis that CBB FX intervention auctions affect the exchange to some degree. In contrast to the others, our research uses the liquidity and price discovery indexes to investigate the market's behavior concerning this new information.

Our contribution to this literature is to give a new approach to investigate the CBB interventions impacts on the foreign exchange market. Furthermore, it could be joined to event study methodology in the future.

\section{Methodology}

\subsection{Liquidity Indexes}

For market liquidity study, this research uses the illiquidity indexes from Hasbrouck and Levich (2019) and Mancini et al. (2013). These measures provide tools to investigate the market activity and how market participants behaved in the presence of CBB FX intervention auctions.

Consider $P_{A}$ the best ask quote, $P_{B}$ the best bid quote, and $P_{M}$ the middle quote, which is the simple average between the bid and ask prices. The relative bid-ask spread can 
be defined as:

$$
R_{\text {spread }}=\frac{\left(P_{A}-P_{B}\right)}{P_{M}}
$$

where a low relative spread reflects a liquid market, and illiquid otherwise. If the spread is elevated, the dealers are incorporating some trading risk, and they are transmitting it into prices to balance their expected profits.

In the same way, Hasbrouck and Levich (2019) proposed two illiquidity indexes based on Amihud (2012) and Barardehi et al. (2018). The authors defined the illiquidity ratio $I_{k}$ over an interval $k$ as:

$$
I_{k}=\frac{\left|\Delta p_{k}\right|}{\text { Volume }_{k}}
$$

where $p_{k}$ is the log price, and $\Delta p_{k}=\sum_{j} \Delta p_{j}$ is the sum of the returns over the interval $k$. Moreover, the Volume $_{k}=\sum_{j}\left|x_{j}\right|$ is the sum of individual volumes comprised in the interval $k$, where $x_{j}$ is the quantity of the $j^{t h}$ incoming active order, signed positive for buying and negative for selling. ${ }^{2}$

The authors specified two indexes. One is the $I_{k}^{\text {Time }}$, which contemplates the illiquidity ratio over a two-minute interval with non-zero settlement volume, and the second one is the $I_{k}^{V o l u m e}$ which specify the illiquidity ratio over intervals with $\$ 100 \mathrm{M}$ USD cumulative settlement volume. In our case, the $I_{k}^{\text {Time }}$ comprises a 1-minute break.

They argued that $I_{k}^{V o l u m e}$ is preferred over $I_{k}^{\text {Time }}$. Because the former better captures institutional costs (Barardehi et al., 2018), and the latter presents some problems with outliers.

Other liquidity measures are the Price impact and the Return reversal based on Mancini et al. (2013). The greater the impact of order flow in the exchange rates, the lower the market liquidity. Consider $r_{t_{i}}$, that is the difference between the natural logarithm of the exchange rates in period $t$ and $t-1, v_{b, t}$ the volume of the buyer and $v_{s, t}$ the seller-initiated, order flow as the difference $v_{b, t}-v_{s, t}$, at time $t$ :

$$
r_{t}=c+r_{t-1}+\varphi_{t}\left(v_{b, t}-v_{s, t}\right)+\sum_{k=1}^{K} \gamma_{t, k}\left(v_{b, t-1}-v_{s, t-1}\right)+\varepsilon_{t_{i}}
$$

where $\varepsilon_{t_{i}}$ is an error term, normally distributed with zero mean and variance $\sigma_{\varepsilon}^{2}$.

The price impact, $\varphi_{t}$, measures the magnitude of the current order flow on the

\footnotetext{
${ }^{2}$ They argued that illiquidity ratios covering intervals are better than indexes build on the end intervals values because they may not capture the trading dynamics over a period.
} 
exchange rate returns. The price impact should be positive due to net buying pressure. The overall return reversal is the $\sum_{k=1}^{K} \gamma_{t, k}$, and reflects the lagged impact of the order flow in the exchange rate returns. Later, we also included some dummy variables to verify possible CBB FX intervention auctions effects.

Those measures provide a framework to comprehend the market liquidity along the day, and mainly, an understanding of how market participants behaved during the CBB FX programmed and non-programmed intervention auctions.

\subsection{Price Discovery}

In order to analyze the contribution of bid (buy-side) and ask (sell-side) quotes to price discovery in the Brazilian FX futures market, this study relies on the most common price discovery metrics, the "Information Share" (IS) from Hasbrouck (1995), and the "Component share" from Booth et al. (1999), Chu et al. (1999), and Harris et al. (2002), based on Gonzalo and Granger (1995) common factor decomposition. Both metrics rely on an error-correction model from Engle and Granger (1987).

The Information Share (IS) decomposes the implicit efficient price variance and attributes the more outstanding share to the quote that exhibits a higher contribution to that variance. Besides, the Component Share (CS), based on the permanent-transitory decomposition of Gonzalo and Granger (1995), considers the leading quote, the one with the highest weight on the common factor. Furthermore, Baillie et al. (2002) demonstrated that these two measures are related, and they produce consistent results when the same information flow affects both buyer and seller-sides.

Suppose that $\mathbf{p}_{\mathbf{t}}=\left(p_{a s k}, p_{b i d}\right)^{\prime}$ is a vector of natural logarithm of ask and bid quotes. Consider the non-arbitrage hypotheses and assume that each quote contains a random walk component. Then, they are considered integrated of order $1, \mathrm{I}(1)$, and the first difference, $\Delta \mathbf{p}_{\mathbf{t}}$, is covariance stationary. Assuming that the bid and ask quotes cointegrated, it is possible to use a vector error-correction model (VECM) to analyze their long and short-term dynamics:

$$
\Delta \mathbf{p}_{\mathbf{t}}=\boldsymbol{\alpha}\left(\mathbf{p}_{\mathbf{a s k}, \mathbf{t}-\mathbf{1}}-\boldsymbol{\beta} \mathbf{p}_{\mathbf{b i d}, \mathbf{t}-\mathbf{1}}+\mathbf{c}\right)+\Gamma_{1} \Delta \mathbf{p}_{\mathbf{t}-\mathbf{1}}+\Gamma_{2} \Delta \mathbf{p}_{\mathbf{t}-\mathbf{2}}+\ldots+\Gamma_{k} \Delta \mathbf{p}_{\mathbf{t}-\mathbf{k}}+\boldsymbol{\epsilon}_{\boldsymbol{t}}
$$

where $\boldsymbol{\alpha}=\left(\alpha_{1}, \alpha_{2}\right)$ is an error-correction vector for each quote, $\boldsymbol{\beta}=(1,-1)^{\prime}$ is the cointegration vector, and $\boldsymbol{\epsilon}_{\boldsymbol{t}}=\left(\epsilon_{t}^{1}, \epsilon_{t}^{2}\right)$ is a vector of innovations with zero mean and serially uncorrelated, 
with variance $\Omega$. The $\boldsymbol{\alpha}$ can be interpreted as the speed of adjustment of the bid and ask quotes to the equilibrium price, and $\boldsymbol{\beta}$ as the coefficient of cointegration which secures the long-term equilibrium among the quotes.

To construct the IS metric, equation (4) can be rewritten as a vector moving average (VMA), representing prices changes exclusively in terms of the current and the past innovations:

$$
\Delta p_{t}=\Psi_{0} \epsilon_{t}+\Psi_{1} \epsilon_{t-1}+\Psi_{2} \epsilon_{t-2}+\ldots=\Psi(\mathbf{L}) \epsilon_{t}
$$

where $\boldsymbol{\Psi}(L)=\sum_{k=0}^{\infty} \mathbf{\Psi}_{k} L^{k}, \boldsymbol{\Psi}_{\mathbf{0}}=\mathbf{I}$ is a $2 \mathrm{x} 2$ identity matrix, and $\boldsymbol{\epsilon}_{\boldsymbol{t}}$ is a $2 \mathrm{x} 1$ vector with $E\left[\boldsymbol{\epsilon}_{\boldsymbol{t}}\right]=0$.

Using the Beveridge-Nelson (BN) trend-cycle decomposition (Beveridge and Nelson, 1981) in (5), we have:

$$
\mathbf{p}_{\mathbf{t}}=\mathbf{p}_{\mathbf{0}}+\boldsymbol{\Psi}(1) \sum_{s=1}^{t} \boldsymbol{\epsilon}_{s}+\mathbf{\Psi}^{*}(L) \boldsymbol{\epsilon}_{\boldsymbol{t}}
$$

where $\mathbf{p}_{\mathbf{0}}$ is a vector of initial values, reflecting nonstochastic differences between prices. The second term reflects a common component, which is, in our case, the efficient price. And, the last term is the residual with a zero-mean covariance stationary process. If the bid and ask quotes are cointegrated, all rows in $\boldsymbol{\Psi}(1)$ are equal. Then, the common row of $\boldsymbol{\Psi}(1)$ can be written as $\boldsymbol{\psi}=\left(\psi_{1}, \psi_{2}\right)$, and the variance of the efficient spread innovations can be calculated by $\psi \Omega \psi^{\prime}$.

Based of those definitions, Hasbrouck (1995) developed the information share (IS) metric. Considering the VMA residuals are uncorrelated, the IS can be written as:

$$
\mathrm{IS}_{i}=\frac{\psi_{i}^{2} \Omega_{i i}}{\psi \Omega \psi^{\prime}}
$$

where $\psi_{i}$ is the $i$ th element of $\Psi, \Omega_{i i}$ is the $(i, i)$ element of the residuals covariance matrix, $i=1,2$.

When the residuals are correlated, the IS measure has a problem with the covariance terms. In this case, Hasbrouck (1995) proposed a method to calculate the IS via Cholesky decomposition of $\Omega=F F^{\prime}$, imposing a hierarchical set that maximizes the information share at the top and minimizes the bottom. So, it is possible to establish the superior and inferior 
bounds for the IS measures:

$$
\mathrm{IS}_{i}=\frac{\left([\psi F]_{i}\right)^{2}}{\psi \Omega \psi^{\prime}}
$$

where $[\psi F]_{i}$ is $i$ th element of the row matrix $[\psi F]$. Given the IS range, Hasbrouck (1995) uses the average between the upper and lower bounds to establish an IS metric.

Then, the information share (IS) can be interpreted as the contribution of each quote to the variance of the efficient price, in our case, the efficient spread.

The other price discovery metric is the component share (CS), which relies on Gonzalo and Granger (1995) Permanent-Transitory decomposition method and in a fully specified vector error-correction model (VECM) from Engle and Granger (1987). Gonzalo and Granger (1995) proposed an alternative approach to decompose a variable into a permanent and a transitory component. But, the permanent component calculation requires two properties. First, it needs to be a linear combination of the contemporaneous prices, and second, the transitory component does not Granger-cause the permanent component in the long term.

In this way, the decomposition of the price vector $\mathbf{p}_{\mathbf{t}}$ as the sum of the permanent component $\left(f_{t}\right)$ and the transitory $\left(z_{t}\right)$ component could be written as:

$$
\mathbf{p}_{\mathbf{t}}=A_{1} f_{t}+A_{2} z_{t}
$$

Once the common factors $f_{t}$ are identified, is possible to obtain the P-T decomposition proposed by Gonzalo and Granger (1995):

$$
\mathbf{p}_{\mathbf{t}}=A_{1} \boldsymbol{\alpha}_{\perp}^{\prime} \mathbf{p}_{\mathbf{t}}+A_{2} \boldsymbol{\beta}^{\prime} \mathbf{p}_{\mathbf{t}}
$$

where $f_{t}=\boldsymbol{\alpha}_{\perp}{ }^{\prime} \mathbf{p}_{\mathbf{t}} \sim I(1)$ and $z_{t}=\boldsymbol{\beta}^{\prime} \mathbf{p}_{\mathbf{t}} \sim I(0)$. The $\boldsymbol{\alpha}_{\perp}$ is orthogonal to the speed of adjustment vector $\alpha$, and presents the common factor component weights of ask and bid quotes.

Within this framework and with the estimation of equation (4), it is possible to obtain the speed of adjustment $\boldsymbol{\alpha}$, and consequently, the $\boldsymbol{\alpha}_{\perp}$. With the $\boldsymbol{\alpha}_{\perp}$, it is feasible to find the weights of each quote to the permanent component formation. Booth et al. (1999), Chu et al. (1999), and Harris et al. (2002) proposed using those weights to investigate the contribution of each market, in our case bid and ask quotes, to price discovery. Additionally, de Boyrie et al. (2012) and de Jong (2002) associate those weights with the long-term matrix 
$\Psi(1)$. So, the component share (CS) can be written as:

$$
\mathrm{CS}_{i}=\frac{\alpha_{\perp_{i}}}{\alpha_{\perp_{1}}+\alpha_{\perp_{2}}} \text {, or equivalently, } \mathrm{CS}_{i}=\frac{\psi_{i}}{\psi_{1}+\psi_{2}},
$$

where $i=1,2$, and $\left(\psi_{1}, \psi_{2}\right)$ are the each market long-run coefficient from the $\Psi(1)$ matrix.

A higher (small) value of CS implies a greater (lower) contribution of quote $i$ to price discovery. If, for example, the bid quote presents a higher CS value than the ask quote, the former is considered the informational leader of the market.

In summary, this methodology will help us analyzing whether the buy-side or sell-side has more information about the price discovery process within the CBB FX intervention scope.

\section{Data}

This study relies on high-frequency data. Because of the data granularity, it is possible to investigate the effects of new information on the market and how it is assimilated by market agents and passed into prices.

A second important issue about the data is that this study only focuses on the Brazilian foreign exchange futures market. Besides data availability, the Brazilian FX futures market offers more liquidity and volume than the spot market. Ventura and Garcia (2012), Garcia and Urban (2004) claimed that the limited access to the Brazilian FX spot market, due to the CBB institutional framework, made typical international operations be transferred to the Brazilian FX futures market at its first maturity since the futures market is much less restrictive. Consequently, market participants prioritize the futures market when carrying out their foreign exchange operations, making the volume traded on the FX futures market greater than the volume traded on the spot market. ${ }^{3}$

With this perspective, the one trading day strategy considers November $26^{\text {th }}, 2019$, which presented a large number of CBB FX intervention auctions, and intriguing foreign exchange rates dynamic.

The high-frequency database was provided by the Brazilian Stock Exchange Market (B3) and contemplated tick-by-tick trading prices and bid-ask quotes, with their respective

\footnotetext{
${ }^{3}$ Ventura and Garcia (2012), and Garcia et al. (2015) used the microstructure framework to examine the foreign exchange price formation. Considering Granger causality and price discovery metrics, they showed that exchange rate formation originates first in the futures market and then transferred to the spot market via arbitrage. Garcia et al. (2015), claimed that the futures market adjusts more quickly to new information due to superior levels of liquidity and transparency.
} 
contract quantities, buy-sell aggressor signals, and financial and non-financial institutional code numbers. Our raw data, which comprises all contracts negotiated on that day and buy and sell sides for all types of orders, contemplates 1,346,299 observations.

For auction information, there were two sources: the "BC Correio" platform and Trading News Broadcast. The former provides the exact time that announcements were released to the public and additional details about the CBB auctions such as a spot or a futures market auction; a buy or sell auction; the period for bids completion; the minimum lot, and the lowest acceptable bid for the lot. The latter is a financial news platform that bunches stock market auction detailed information and real-time financial news.

\section{$4.1 \quad$ November $26^{\text {th }}, 2019$}

On November $26^{\text {th }}, 2019$, there were seven foreign exchange auctions. The Central Bank announced three of them the day before, and four were non-programmed auctions. A full auction description is made along this section. Against this background of many FX auctions, this day provides good elements to our investigation.

In addition to this large amount of intervention auctions, a series of occurrences on the Brazilian foreign exchange market motivated the Brazilian central bank to step in on this day.

On an upward trend since 2018, the foreign exchange rates were at a historical maximum on On November $26^{\text {th }}, 2019$. The PTAX, the daily market reference price published by the CBB, was 4,2559 BRL/USD, the highest rate since the "Plano Real" (1994). Figure 1 shows the respective daily price since 2000 .

As possibly seen by the market, this new historical foreign exchange high resulted from the positive outlook for the ongoing trading agreement between the USA and China. Domestically, they were the fall out of declarations by the Brazilian finance minister, Paulo Guedes, on interest and exchange rates, and a mention of the AI-5, an institutional act used by the Brazilian dictatorial regime (1964-1985) to suspend any constitutional guarantees, to close the National Congress, to intervene in states and municipalities, among other authoritarian measures.

These two reports triggered an upward move in the spot and the futures foreign exchange rates throughout the day. 


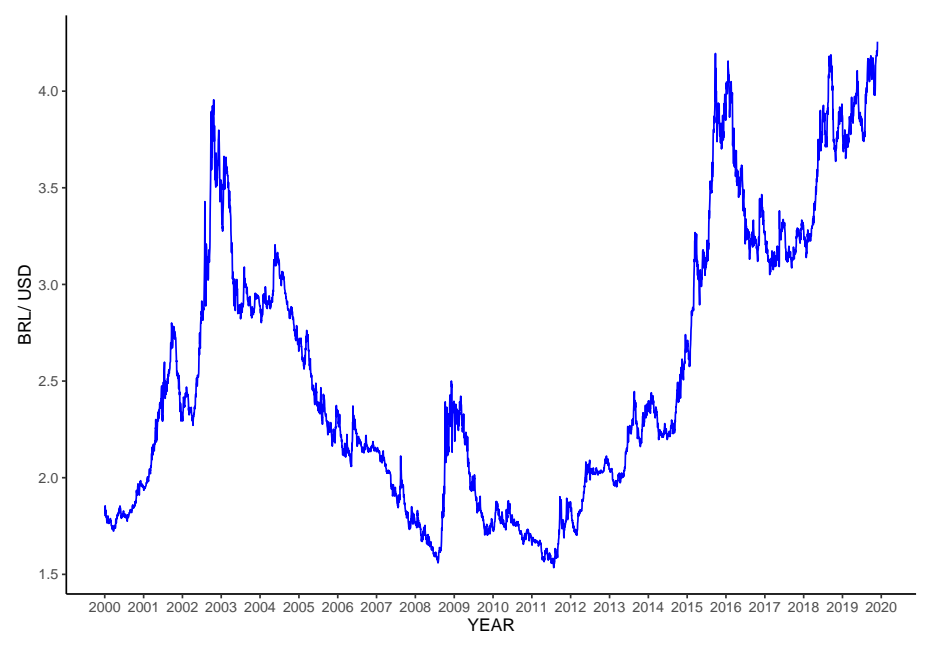

Figure 1: PTAX: January 3, 2000 to November 26, 2019

Source: Central Bank of Brazil

Internationally, according to Trading News Broadcast, there was definite progress on US-China preliminary "phase 1" trade agreement. That day, U.S. and China authorities met to work out a deal to end the ongoing trading war between the two countries. The U.S. President Donald Trump's optimistic declaration on the agreement pushed the U.S. stock markets higher.

The Federal Reserve Chair Jerome Powel's remarks about the U.S. monetary policies and the interest rate levels have also welcomed the news and helped boost the stock market. The dollar was up against some major currencies such as the yen, the pound, and some emerging market currencies. Besides the possible trade deal and FED Chair's declaration, international markets factored in an expected extension of crude oil production cuts by OPEP and Russia.

Domestically, the upward trend in the BRL-USD rate was due to two statements by the finance minister Paulo Guedes' in Washington at an evening press conference on November $25^{\text {th }}, 2019$.

Earlier, former president Luiz Inácio Lula da Silva's strongly suggested that Brazilians take to the street and rally against the Brazilian government's policies as was happening in Chile and Bolivia. In response, according to the Brazilian journal "Estado de São Paulo", Paulo Guedes declared that those suggestions were irresponsible to democracy and that kind of statements could lead someone to ask for the AI-5.

Guedes' pronouncement came following the president son's declaration in October, 
defending measures such as AI-5 to curb possible street demonstrations if the opposition called the population to the streets.

At the press conference, Guedes had more to say about the interest and foreign exchange rates. With the interest rate at its lowest historical level and on a downward trend, and the foreign exchange rate upward trend, the finance minister declared that he was not concerned by the dollar moving higher than 4.20 BRL/USD. Further comments by Brazilian president Jair Bolsonaro did not alleviate market volatility.

Furthermore, the Trading News Broadcast reported that due to Morgan Stanley Capital International Index (MSCI) re-balancing, the closing trading session for futures contracts and options was delayed by thirty minutes. The FX derivatives market opened at 09:00 a.m. and closed at 06:30 p.m. This re-balancing also put pressure on exchange rates, as it generated the selling of stocks in the Brazilian market and withdrew funds from Brazil. Table 1 presents the main news on that day.

In this context, our attention turns to the foreign exchange futures market, more specifically, to the foreign exchange contract DOLZ19. This contract is defined as BRL per USD 1,000, and his maturity was on the first business day of December 2019. Moreover, each contract is worth USD 50,000.00. Our tick-by-tick trading price data contemplates 62,666 observations.

On November $26^{\text {th }}, 2019$, the DOLZ19 trading price registered a $-0,37 \%$ daily price variation, with a maximum of $+0,62 \%$ and a minimum $-0,48 \%$ - relative to the opening price, BRL 4,251.0. It is worth mentioning that there were three days to contract maturity, so the futures price was approximately the spot price.

For most of the open hours, the DOLZ19 trended up, reversing only after the CBB's last intervention in the afternoon. Figure 2 presents the trading price per second during the day. Table 3 shows their descriptive statistics.

As mention before, we use tick-by-tick data, but all graphs showed in this section are aggregated by seconds for better visualization. The dashed lines represent the time of the intervention auction announcements, and the blue columns illustrate the period for bid reception by the $\mathrm{CBB}$. 


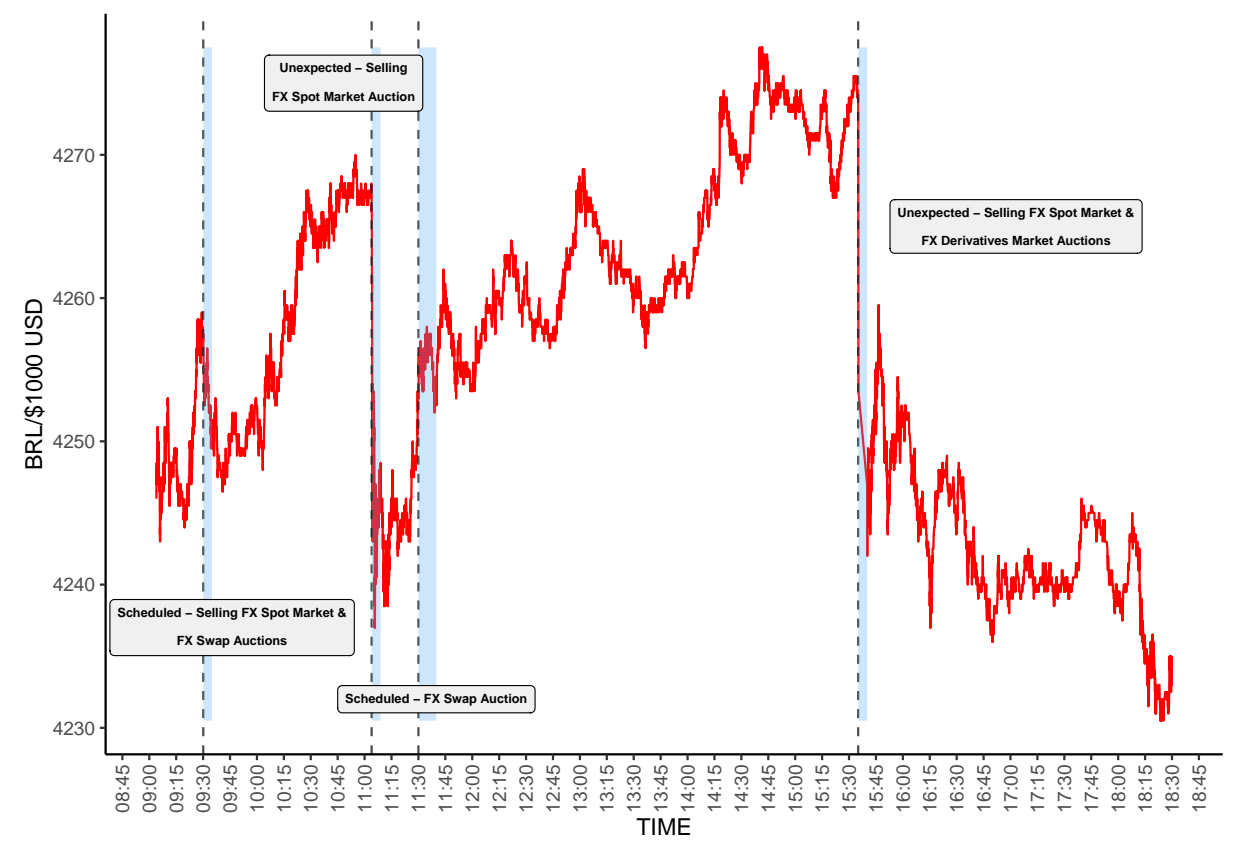

Figure 2: Trading price per second

Source: B3

At 08:55 a.m., the DOLZ19 pre-open market auction started. At this auction session, according to the B3's trading rulebook, the market participants can launch bid and ask quotes in the central order book, but transactions are not permitted. The opening price will maximize the number of derivatives traded in the call ${ }^{4}$. Table 2 gives detail information about the FX auctions, and it is sort by the announcement date-time.

\footnotetext{
${ }^{4}$ B3's trading rulebook: Chapter IV, Section VIII: Opening Call and Closing Call
} 
Table 1: Main News

\begin{tabular}{cl}
\hline Time & Reports \\
\hline 08:38 a.m. & "The Weekly Consumer Price Index (IPC-S) rose in all seven state capitals surveyed in the third week of November - Fundação Getulio Vargas (FGV)" \\
08:46 a.m. & "The Construction Confidence Index (ICST) rose 1.5 points in November, to 89.0 points, reaching the highest level since September 2014 (89.9) - Getulio Vargas Foundation (FGV)" \\
09:04 a.m. & "The Construction Cost National Index - Market (INCC-M) accelerated to 0.15\% in November, after changing 0.12\% in October - Fundação Getulio Vargas (FGV)" \\
11:14 a.m. & "The Brazilian business' confidence reached its highest level in seven months in November - National Confederation of Goods, Trade, Services and Tourism (CNC)" \\
11:30 a.m. & "The US trade deficit was narrowed from $\$ 70.5$ billion in September to $\$ 66.5$ billion in October - The Census Bureau" \\
12:14 p.m. & "The U.S. Conference Board Consumer Confidence Index dropped from 126.1 in October to 125.5 in November - The U.S. Conference Board" \\
02:25 p.m. & "The Brazilian Monthly Federal Public Debt (DPF) fell 0.84\% in October - The National Treasury" \\
05:37 p.m. & "Brazilian international reserves fell by US $\$ 169$ million on Monday, 25 - Central Bank of Brazil" \\
\hline
\end{tabular}

Table 2: Auctions

\begin{tabular}{|c|c|c|c|c|c|c|c|c|}
\hline Number & Anouncement Date & Announcement Time & Operation Date & Period for settle the bids & Auction & Market & Value (USD millions) & Quantity \\
\hline 34.744 & $11 / 25 / 2019$ & 06:15:07 p.m. & $11 / 26 / 2019$ & 9:30 a.m. - 09:35 a.m. & Sell & Spot & 785 & - \\
\hline 34.745 & $11 / 25 / 2019$ & 06:15:09 p.m. & $11 / 26 / 2019$ & 9:30 a.m. - 09:35 a.m. & Swap & Futures & 785 & 15700 \\
\hline 34.746 & $11 / 25 / 2019$ & 06:16:01 p.m. & $11 / 26 / 2019$ & 11:30 a.m. - 11:40 a.m. & Swap & Futures & [785 - USD R*50] & {$[15.700-R]^{\mathrm{a}}$} \\
\hline DOLZ19 I-1 & $11 / 26 / 2019$ & 09:00:00 a.m. & $11 / 26 / 2019$ & - & - & Futures & - & - \\
\hline 34.755 & $11 / 26 / 2019$ & 03:35:06 p.m. & $11 / 26 / 2019$ & 03:35:06 p.m. - 03:40:06 p.m. & Sell & Spot & Minimum Lot: USD $1,000,000.00$ & - \\
\hline DOLZ19 I-2 & $11 / 26 / 2019$ & 03:35:15 p.m. & $11 / 26 / 2019$ & - & - & Futures & - & - \\
\hline
\end{tabular}

a Note: The "R" is the value of adjustment of the quantity object of this public offering, and corresponds to the number of contracts sold by the Central Bank of Brazil in public offers made on the same date of this offer until 11:30 am. In the case of " $\mathrm{R}$ " greater than or equal to 15,200 contracts, this offer is automatically canceled and the resulting amount of (15,700 - R) will be added to the quantity offered in the traditional swap auction to be held on the following day. 
Table 3: Descriptive statistics

\begin{tabular}{cccccc}
\hline DOLZ19 & Trading Price & No. Contracts & Total Vol (USD billion) & Duration (secs) & Order Flow (USD billion) \\
\hline Minimum & 4230.5 & 5.0 & 0.00025 & 0.00 & -0.0155 \\
1st Q. & 4247.0 & 5.0 & 0.00025 & 0.00 & -0.0003 \\
Median & 4254.5 & 5.0 & 0.00025 & 0.00 & 0.0003 \\
Mean & 4255.1 & 9.64 & 0.00048 & 0.54 & 0.0000 \\
3rd Q. & 4263.0 & 5.0 & 0.00025 & 0.05 & 0.0003 \\
Max & 4277.5 & 9950 & 0.4975 & 289.33 & 0.0238 \\
Stand. Dev. & 9.97 & 75.08 & 0.0038 & 2.20 & 0.0006 \\
\hline Sample Size & 62,666 & 62,666 & 62,666 & 62,665 & 61,633
\end{tabular}

Traditionally, at 09:00 a.m., the foreign exchange futures market opens. However, on this day, according to the Trading News Broadcast, the DOLZ19 pre-open market auction could not determine the opening price, and consequently, given the B3's protection mechanism, it was postponed twice. Subsequently, the first DOLZ19 trade occurred almost 4 minutes later, $0,5 \%$ higher than the closing price on the day before, BRL 4,228.5.

After the opening market, more precisely, twenty minutes later, the DOLZ19 started to move upward, and at 09:29:17 a.m., it reached BRL 4,259.5, the first price peak of the day. Shortly after, the five-minutes receiving bids period for the programmed CBB FX spot and CBB swap auctions opened. Both auctions were announced on the day before, November $25^{\text {th }}$. Considering the bid receiving period for both auctions, 09:30 a.m. to 09:35 a.m., the DOLZ19 prices dropped $0.15 \%$.

At 09:41:27 a.m., the CBB released both auction results: the total volume accepted by the CBB was USD 0.175 billion for the FX spot auction, and in the swap auction, the CBB agreed with 3.500 contracts - USD 0.175 billion total volume. Prices quickly fell, but, ten minutes later, the quotations started to move up again. At 10:54:55 a.m., the DOLZ19 reached BRL 4,270.0, the second peak of the day.

Given the upward trend in prices, as a consequence of the events described at the beginning of this section (mainly by the Brazilian finance minister's declarations), at 11:03:54 a.m., the CBB unexpectedly announced a selling auction on the foreign exchange spot market with a five-minutes bid time, 11:03:54 a.m. to 11:08:54 a.m.

The effects of this non-programmed auction spilled over into the futures foreign exchange market, moving the DOLZ19 prices down for a short while. At the bid receiving period, the price presented a $-0.43 \%$ variation. The CBB released the auction results a few minutes later, but the total volume accepted was not informed.

Unfortunately, the CBB's attempt to alleviate uncertainty and market volatility did not produce the sought-after result, and at 11:26:05 a.m., the DOLZ19 prices started to show an upward trend again. 
At 11:30 a.m., the third programmed CBB FX auction opened his receiving bid period. This auction was announced on the day before, and the receiving bid period by the CBB was between 11:30 a.m. to 11:40 a.m. The CBB did not inform the results of this auction, and the DOLZ19 prices were steady at that receiving bid (-0.01\%). It is worth mentioning that the Trading News Broadcast released, at 11:30 a.m., a statement about the U.S. trade deficit, which was narrowed from $\$ 70.5$ billion in September to $\$ 66.5$ billion in October.

After all those events in the morning, the currency devaluation tendency continued. Throughout the afternoon, some macro announcements were released. The U.S. Conference Board Consumer Confidence Index dropped from 126.1 in October to 125.5 in November, and the Brazilian Monthly Federal Public Debt (FPD) fell 0.84 \% (MoM) in October. Also, there was news about the U.S-China agreement and Brazilian politicians' statements about the finance minister's comments the day before.

At 02:40:07 p.m., the DOLZ19 achieved the maximum of the day, BRL 4,277.5. Then, at 03:35:06 p.m, the CBB announced a new unexpectedly selling intervention auction in the FX spot market, similar to the 11:03:54 a.m. auction, with a five-minute bid time, 03:35:06 p.m. to 03:40:06 p.m. At 03:44 p.m, the CBB released the auction results, but the total volume accepted was not informed.

The effects of this selling spot auction spilled over again into the FX futures market. At the initial bid receiving period by the CBB in the spot market, 03:35:06 p.m., the DOLZ19 contract was negotiated at BRL 4,274.5. After approximately ten seconds, the DOLZ19 prices started a downward trend. The prices fell quickly, and a DOLZ19 auction initiated in the futures market - as a protection mechanism triggered by the B3.

According to Trading News Broadcast, ten DOLZ19 contracts traded at BRL 4,253 were blocked by the B3 since that trading price would be higher relative to the reference price (BRL 4,274.5), 0.5\% maximum allowed by the system. Then, a DOLZ19 auction started, and the trading process halted for approximately 5 minutes. This B3's protection mechanism will be enlightened in the following paragraphs.

The auction dynamic described in the previous paragraph is in accordance with the Trading Tunnels ${ }^{5}$ and Auctions procedures, both described in the B3's trading rulebook, B3's trading procedures manual, and other B3's regulations ${ }^{6}$. Trading tunnels are superior and inferior bands relative to a free trading zone established to mitigate trading risks. According

\footnotetext{
${ }^{5}$ http://www.b3.com.br/en_us/solutions/platforms/puma-trading-system/for-members-andtraders/rules-and-trading-parameters/trading-tunnel/

${ }^{6} \mathrm{http}: / /$ www.b3.com.br/en_us/regulation/regulatory-framework/operational/
} 
to B3's trading rulebook, chapter IV: Trading, Section VII: Trading Tunnels, art.42:

"B3 uses trading tunnels as control mechanisms applicable to the quantities and price fluctuations of the assets and derivatives admitted to trading, with the aim of mitigating the impact of participant failures and operating errors, safeguarding the asset and derivative price formation process, protecting the health and integrity of the markets operated by B3, and avoiding systemic risk." (p.24)

The bounds are defined by the B3 and vary accord to trading asset and trading environment ${ }^{7}$. There are three types of trading tunnels: the rejection tunnel, the auction tunnel, and the projection tunnels. Figure 3 shows the structure of the trading tunnels. Besides, following the B3's trading rulebook, the three tunnels are specified as:

"I - The rejection trading tunnel: prevents registration in the central order book of bids above a specified price or quantity and asks below a specified price or quantity;

II - The auction trading tunnel: automatically submits to an ordinary auction any bids or ask that infringe specified price and quantity limits;

III - The protection trading tunnel during the opening call, closing call, and ordinary auctions: automatically postpones the end of the opening or closing call or of an ordinary auction if the auction price or theoretical quantity infringes a specified limit" (p.25)

As B3's trading rulebook described in the auction periods, only buy and sell orders can be registered, and the negotiations are temporarily halted. The trading time-out is a function of the type of asset or derivatives and the characteristics of the bid and ask quotes submitted to the auction. During this time-out, the bid and ask orders start a "theoretical price" formation process, which is the price that allows the maximum number of transactions to occur at the end of the auction process.

\footnotetext{
${ }^{7}$ http://www.b3.com.br/en_us/solutions/platforms/puma-trading-system/for-members-andtraders/rules-and-trading-parameters/trading-tunnels-parameters /
} 


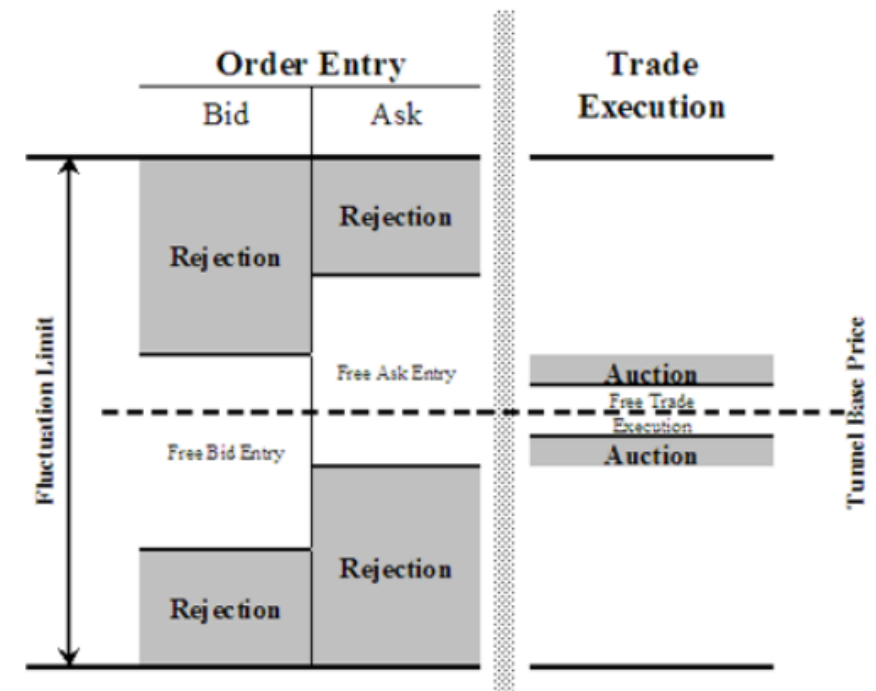

Figure 3: Structure of the trading tunnels

Source: B3

Once the auction is completed, trade could resume with buy offers priced at or higher than the auction price or sell offers priced at or lower than the auction price. Also, as mentioned before, if the auction price or theoretical quantity infringes a specified limit, the auction is postponed.

Considering all these points, the last traded contract before the DOL19 auction was at 03:35:15.662 p.m., and the market re-opened at 03:40:04.999 p.m. with a price variation of $-0,15 \%$. It is worth mentioning that the DOLZ19 auction started and finished during the CBB FX spot market auction period. Then, considering only the bid receiving period at the spot market, the DOLZ19 prices dropped $0.65 \%$.

From then on, DOLZ19 prices showed a downward trend until the end of the day. At closing, delayed until 06:30:00 p.m., the DOLZ19 closed at BRL 4,235.0.

The following schemes give a review of the main events described ins this section, where the first scheme refers to November $25^{\text {th }}$, and the second to November $26^{\text {th }}$. Tables 4 and 5 present price variations. 
November $25^{\text {th }}$

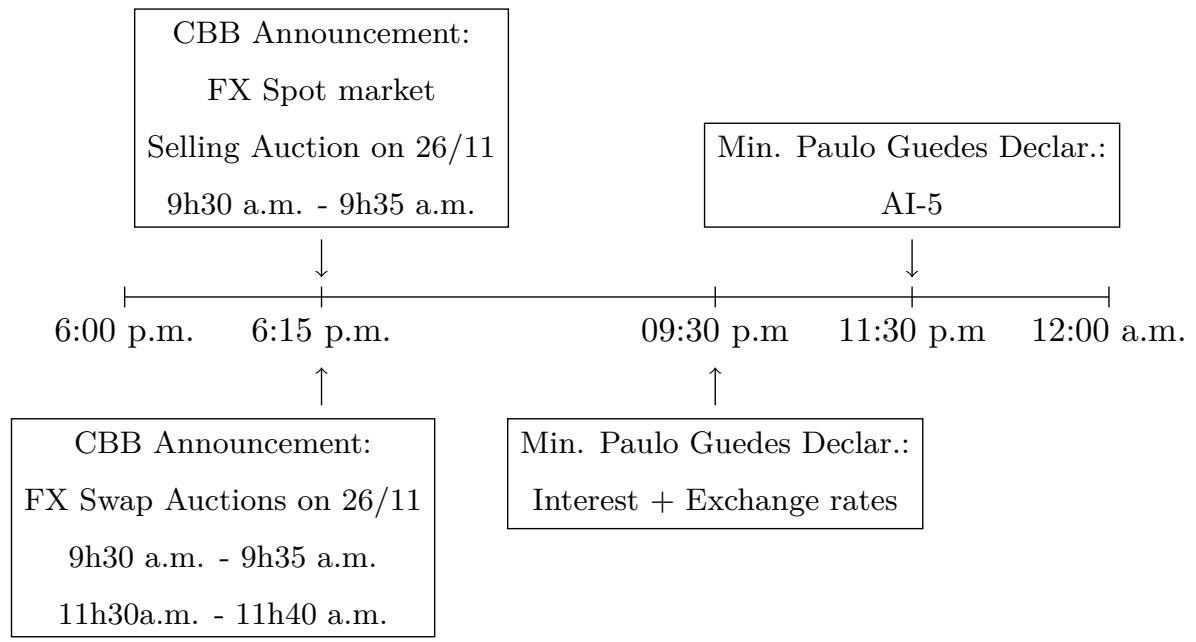

November $26^{\text {th }}$

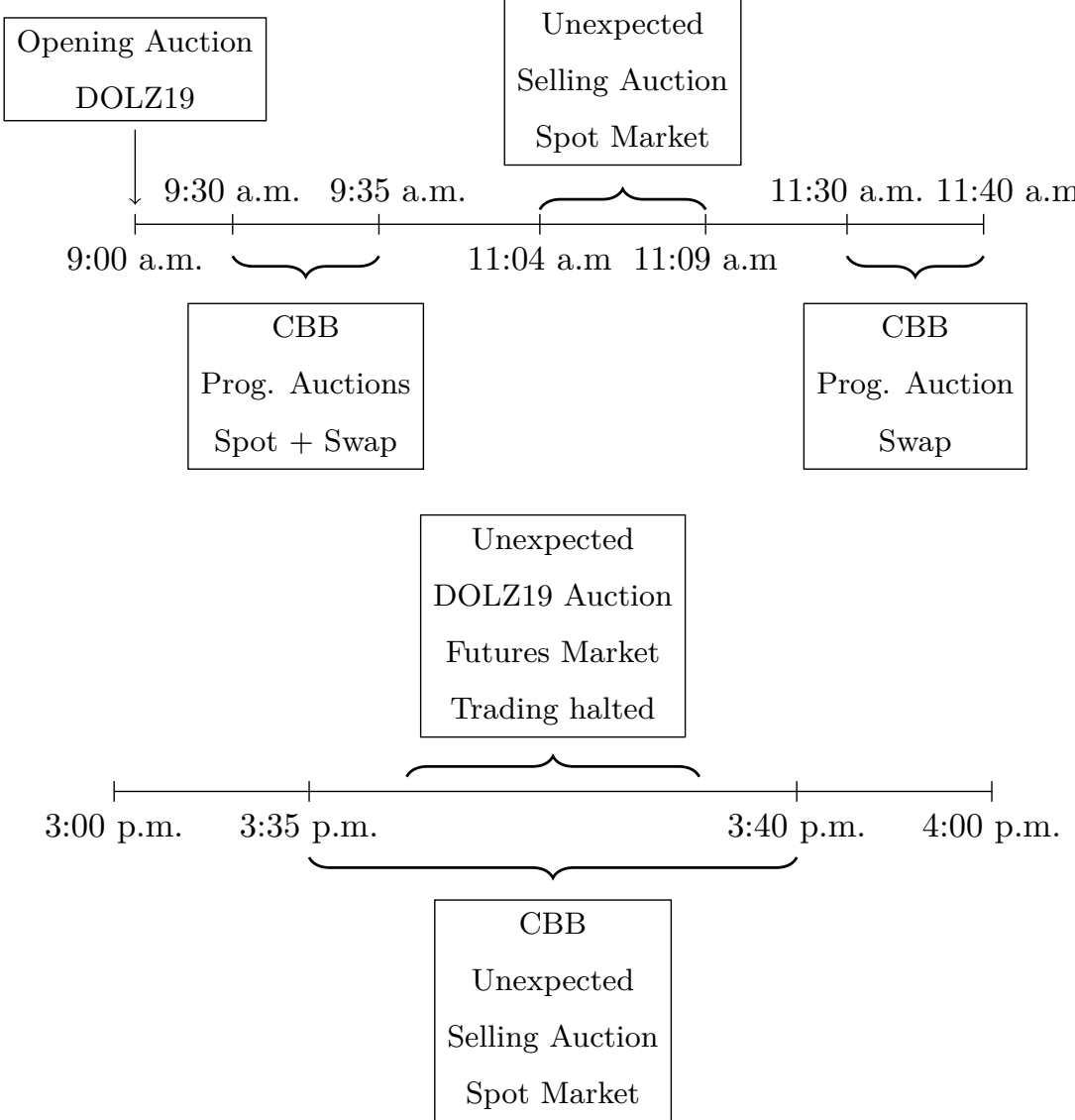


Table 4: Price Variation I

\begin{tabular}{cc} 
Samples & $\Delta P_{t}$ \\
\hline 09:00:00 a.m. - 06:30:00 p.m & $-0.37 \%$ \\
Whole day & \\
\hline 09:30:00 a.m. - 09:35:00 a.m. & $-0.15 \%$ \\
Prog. BCB Auctions & $-0.43 \%$ \\
\hline 11:03:54 a.m. - 11:08:54 a.m. & $-0.01 \%$ \\
Unexp. BCB Auction & \\
\hline 11:30:00 a.m. - 11:40:00 a.m. & \\
Prog. BCB Auction & \\
\hline 03:35:06 p.m. - 03:40:06 p.m. & \\
Unexp. BCB + DOLZ19 Auctions & \\
\hline
\end{tabular}

Table 5: Price Variation II

\begin{tabular}{cc} 
Unexp. BCB + DOLZ19 Auctions & $\Delta P_{t}$ \\
\hline 03:35:06 p.m. - 03:35:15 p.m. & $-0.50 \%$ \\
CBB Announc. - DOLZ19 stop. & \\
\hline 03:35:15 p.m. - 03:40:04 p.m & $-0.15 \%$ \\
Reopening: DOLZ19 trades & \\
\hline
\end{tabular}

\subsubsection{Duration, Volume, and Order flow}

\section{Duration}

One characteristic of our data is that the transaction times between trades and quotes are unequally spaced. Easley and O'Hara (1992) argued that if any factor related to the value of an asset is correlated with the trading time, the presence or absence of trade may convey information to market participants.

Therefore, the authors argued that the duration, the difference between two consecutive orders, may provide relevant information content to the market. Laurini et al. (2008) also claimed that the duration could be related to the arrival of new information in the market, and it is possible to consider as a measure of liquidity ${ }^{8}$.

On that day, the duration presented a daily average of 0.54 seconds, with a standard

\footnotetext{
${ }^{8}$ Dufour and Engle (2000) based on Hasbrouck (1991), presented interesting results about duration, trading activity, and liquidity. They argued that short time duration, and therefore, high trading activity, is related to both more considerable quote revisions and stronger positive autocorrelations of trades.
} 


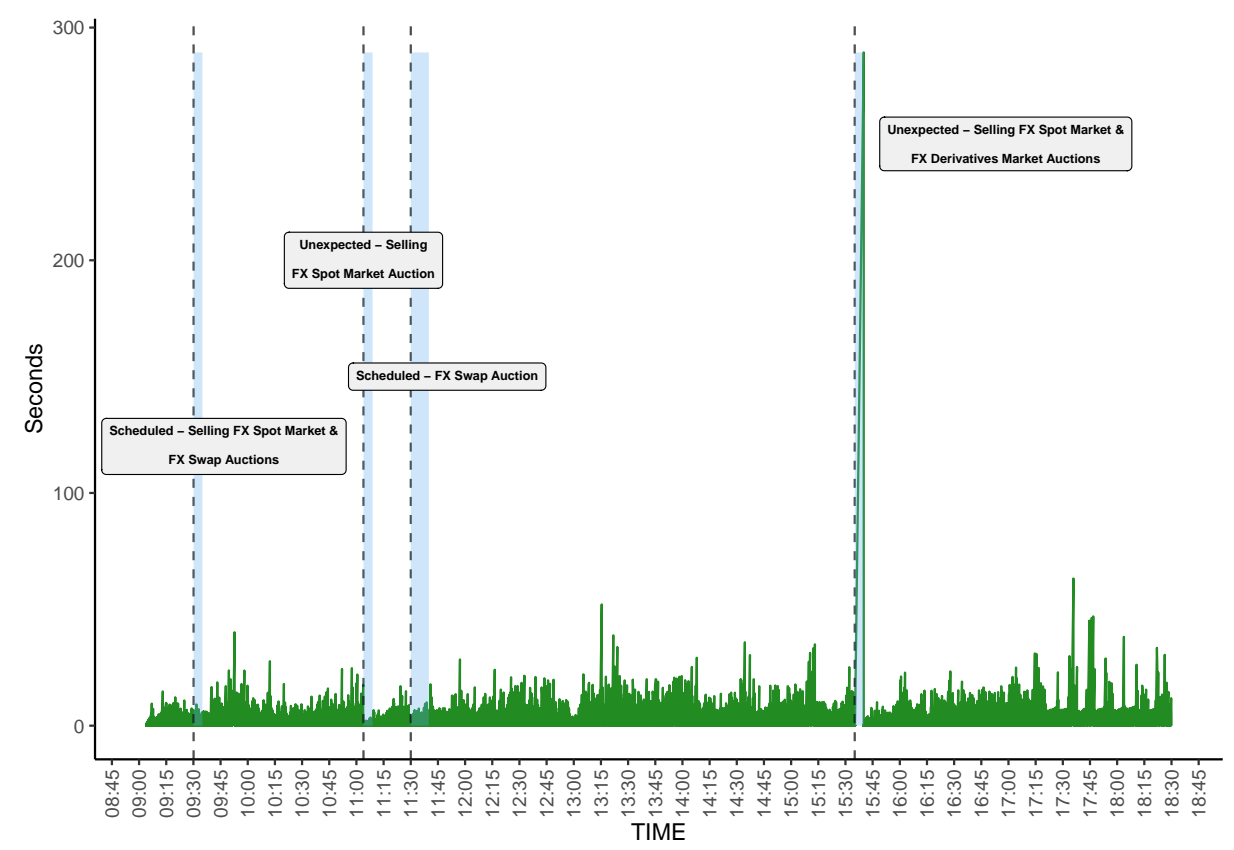

Figure 4: Duration

Source: B3 - Author's own calculations

deviation of 2.20 seconds and a maximum of 289.33 seconds, which is approximately 4.8 minutes. This highest value reflected the halted trading process in the DOLZ19 auction period, from 03:35:15.661 to 03:40:04.999 p.m. Figure 4 shows the duration of the day. Table 3 gives the durations' descriptive statistics.

\section{Volume}

The DOLZ19's total volume was USD 30.2 billion. Hourly, the highest traded volume occurred from 11:00 a.m. to 11:59 a.m., with USD 6.5 billion. The second-highest was from 03:00 p.m to 03:59 p.m, with USD 5.3 billion. It represented $21.7 \%$ and $17.5 \%$ of the daily turnover, respectively. Both high volume periods were related to the two unexpected CBB FX spot market interventions. Figures 5 and 6 show the trading volume per second and hour, respectively. Table 3 gives the descriptive statistics of the volume per billion.

Associated with the CBB FX auctions, the trading volumes were higher than the average daily volume. During the programmed auctions, the trading volumes were 4.4 to 6.14 higher than the daily mean. Moreover, in the first unexpected auction, it was 17.7 times higher. During the last non-programmed auction, the volume was 135.4 higher. 


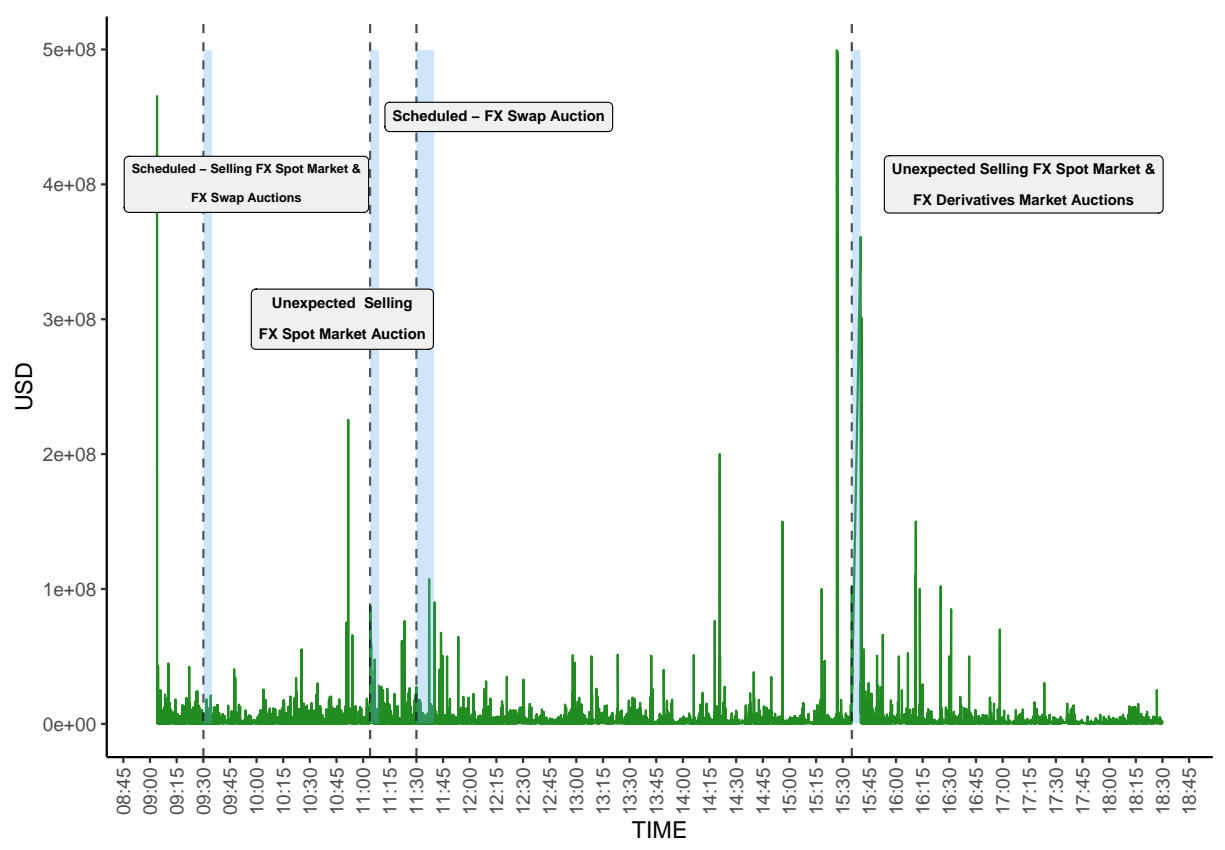

Figure 5: Volume (USD) per second

Source: B3 - Author's own calculations

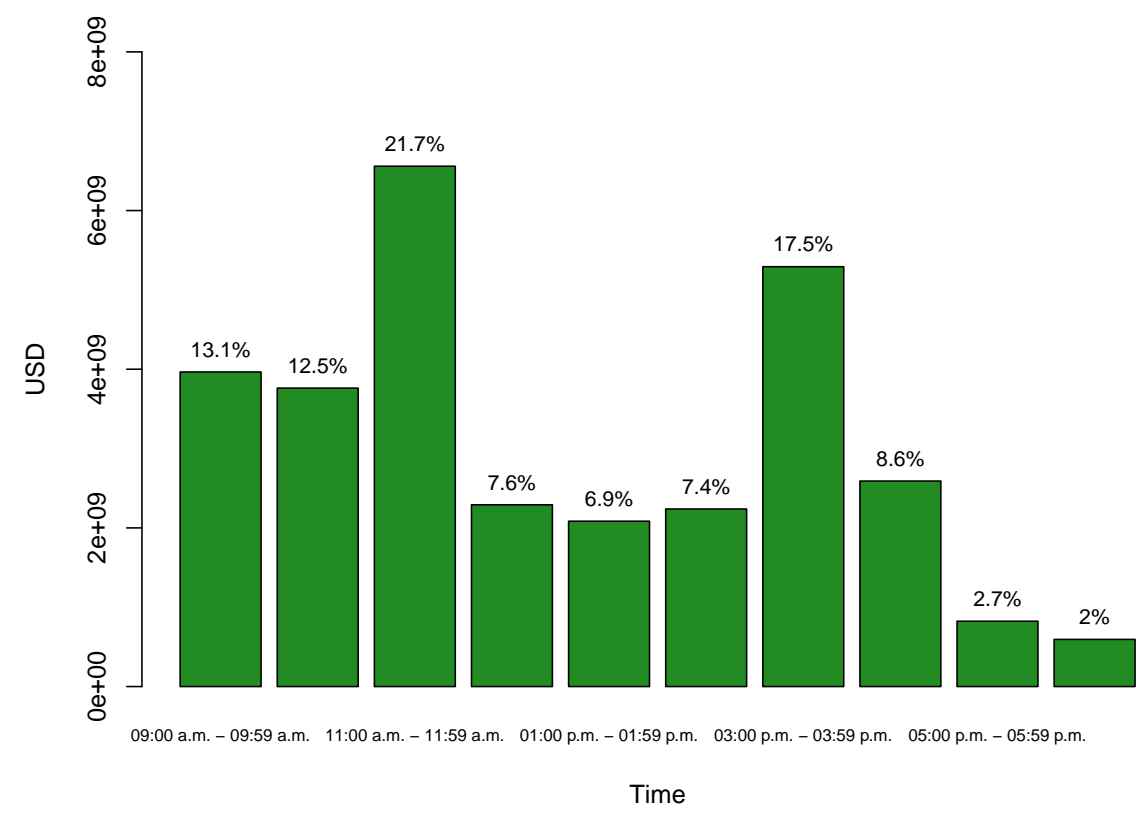

Figure 6: Volume (USD) per hour

Source: B3 - Author's own calculations 


\section{Order Flow}

The order flow was USD 0.528 billion, which means more net buys in the market on that day. Both unexpected auctions were more net-selling intense relative to the programmed auctions. It is important to note that, in non-auction periods, except after the last auction, the order flow presented a net-buy pressure. Table 3 shows the descriptive statistics. Figure 7 illustrates the order flow per second, and figure 8 shows the accumulated order flow with the DOLZ19 trading prices per second.

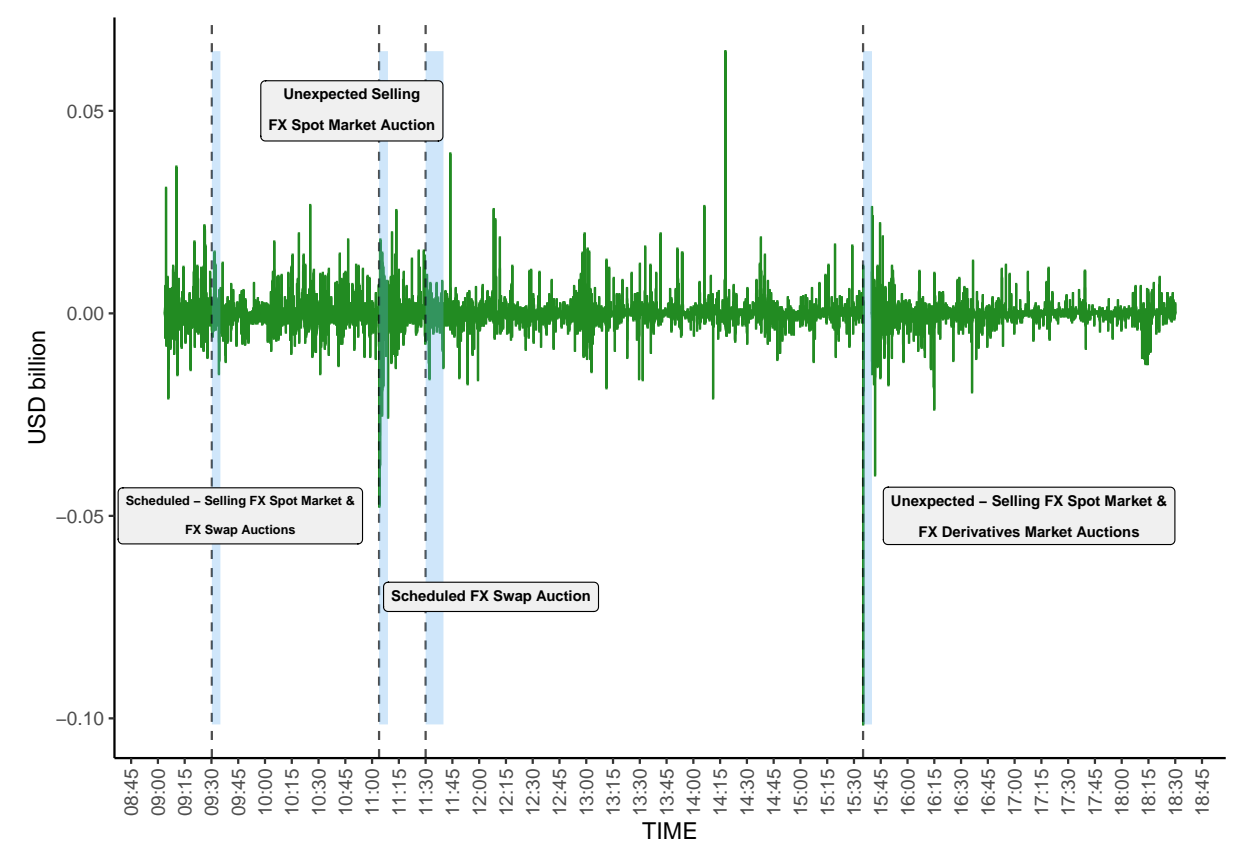

Figure 7: Order flow (USD billion) per second

Source: B3: Author's own calculations 


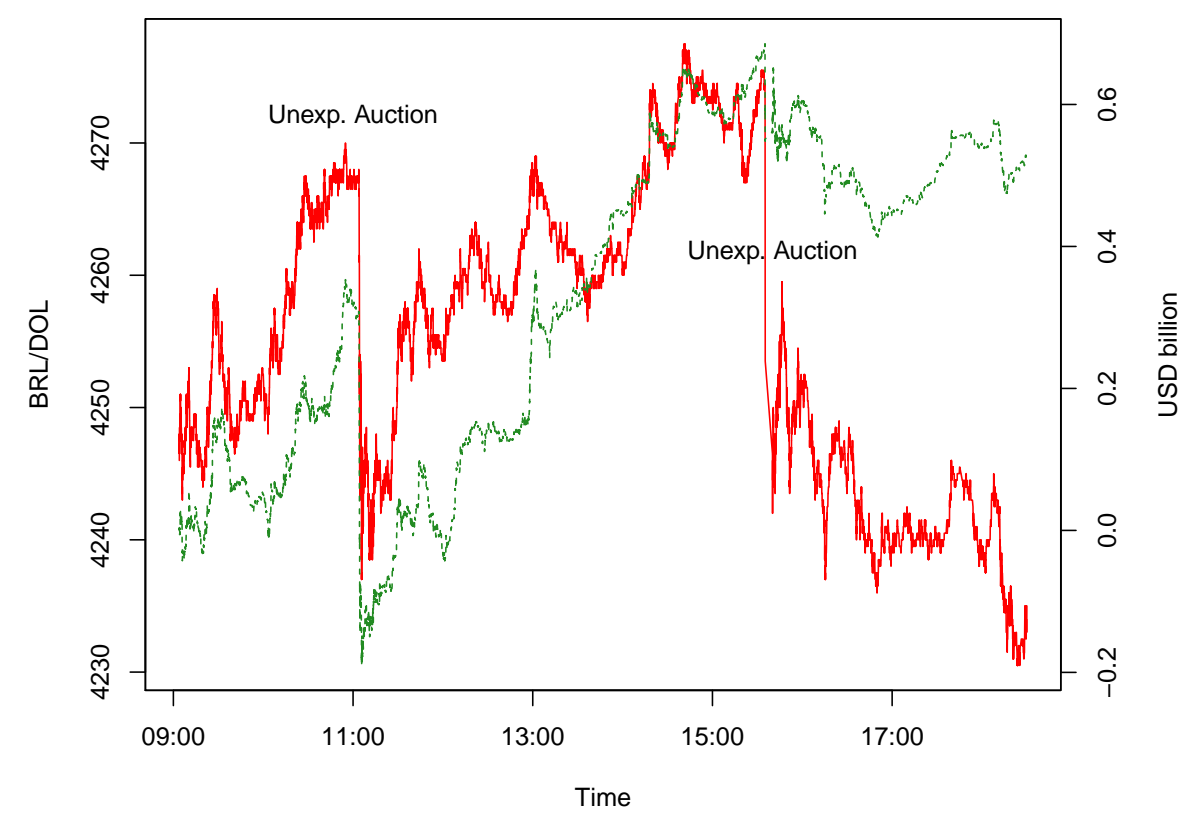

Figure 8: Accum. Order flow per second (Green) x DOLZ19 prices per second (Red)

Source: B3 - Author's own calculations

\subsubsection{Market Participants}

On November $26^{\text {th }}, 2019,39$ institutions participated in DOLZ19 trades, on the buy-side, sell-side, or both. Five of them concentrated more than $50 \%$ of both sides of the market, and three of these five had more than $30 \%$ of it. The main market participants were UBS Brasil, Ideal, BTG Pactual, BGC Liquidez, and XP Investimentos. Additionally, some players showed a significant change in their buy-sell shares during the CBB FX auctions. Table 6 presents the buy and the sell volume share per institution and their respective share during the auctions.

\section{CBB FX auction periods}

During the first programmed FX CBB auction period, from 09:30:00 a.m. to 09:35:00 a.m., UBS Brasil, Bradesco, and J.P Morgan significantly increased their sell share, representing $48.1 \%$ of the total sell-side. As for the buy-side, there were no considerable changes, except for the Ideal, which increased their buy-share by 12.3 p.p. Furthermore, in the second CBB programmed auction period, from 11:30:00 a.m. to 11:40:00 a.m., only Itaú and J.P Morgan presented some changes. 
The relevant cases were the buy-sell shares at the unexpected auctions periods. In the first CBB FX selling spot market auction, three institutions presented an increase in the DOLZ19 selling shares: BTG Pactual, Santander, and CM Capital Markets. Adding the leading market participants, Santander and CM Capital Markets, both buy-side and sell-side shares were $63.6 \%$ and $71.2 \%$, respectively.

During the second CBB unexpected sell auction in the FX spot market, the sell-side share presented the most substantial changes with the reopening trades in the futures market. The BTG Pactual and the Santander represented $42.6 \%$ and $26.1 \%$ of the sell-side shares, respectively. Adding them to UBS Brasil, it was almost $80 \%$ of the sell-side. The buy-side did not present any significant change.

\section{Dealers-14}

An explanation for buy-sell shares variations is a possible spillover from CBB FX spot auctions into the futures market. The CBB FX spot market auctions were realized in the interbank market, a segment of the spot market. As described by Garcia and Urban (2004), the interbank, or secondary market, is a Decentralized Multiple-Dealer Market where authorized financial institutions purchase and sell foreign exchange among themselves for a hedge, arbitrage, and speculation aims.

The CBB can also buy and sell foreign currencies in the spot market, but, by law, those operations are carried out by the International Reserve Department (DEPIN) throughout 14 CBB accredited financial institutions, called Dealers-14.

The Dealers-14 have essential duties such as: participate in foreign exchange auctions promoted by the CBB, quote, whenever requested, purchase and sale rates for foreign currencies, provide liquidity to the foreign exchange market, and participate in conference calls with the Central Bank of Brazil. As they are involved in the CBB FX auctions and participate in DOLZ19 trades, a selling spillover may exist from the spot market to the foreign exchange futures market.

The BTG, J.P Morgan, Bradesco, Itaú, and Santander are Dealers-14, and their sell-side share on auctions increased relative to the daily average. But, this argument is complicated to assess given the non-public information about the winners of those auctions. Table 7 shows Dealers-14 institutional names in November 2019. ${ }^{9}$.

\footnotetext{
${ }^{9}$ In table 6, the bold name enhances the Dealers-14.
} 
Table 6: Buy-sell Volume Shares

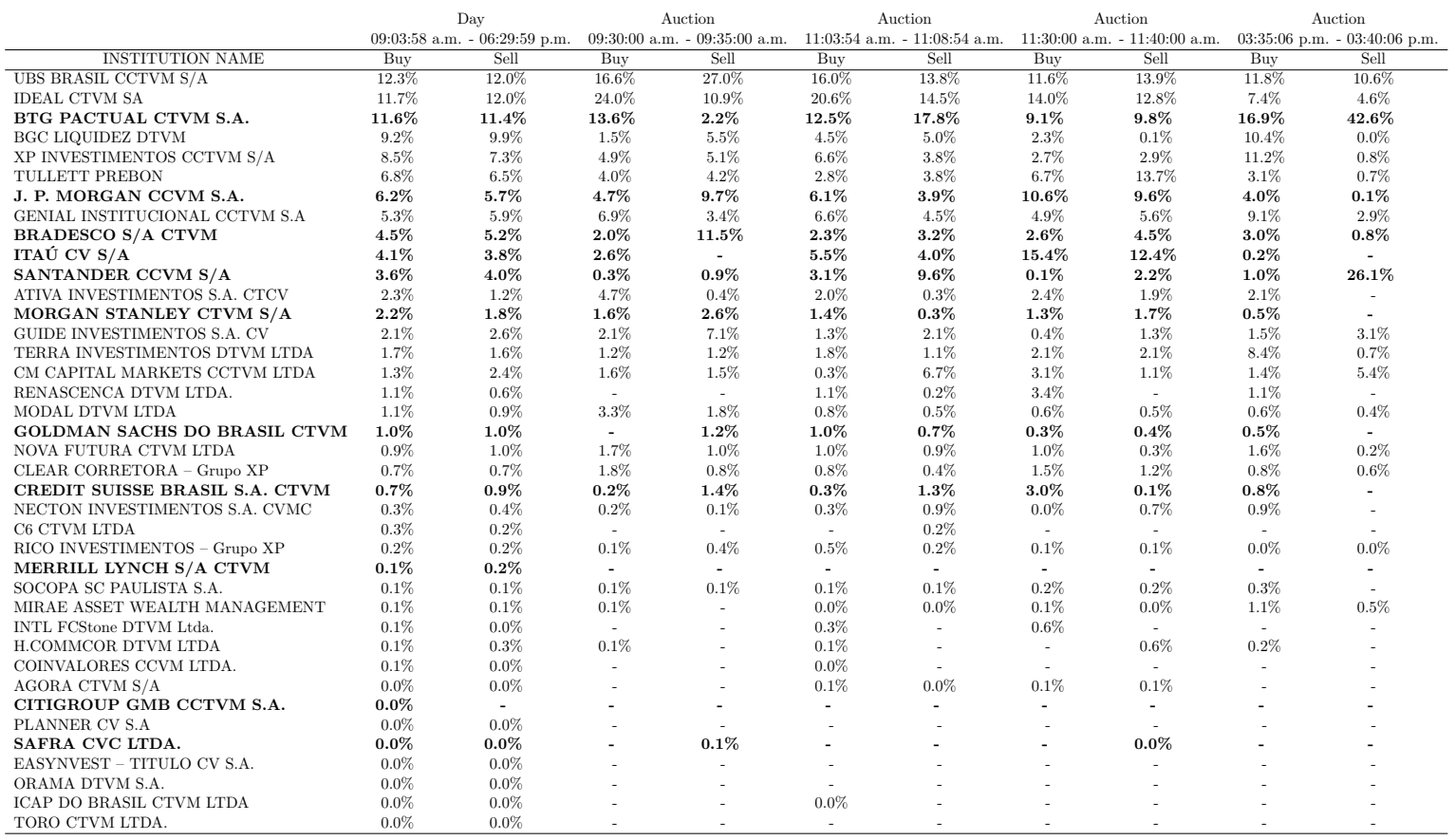

Table 7: FX interbank Dealers-14

\begin{tabular}{|l|}
\hline BANCO DO BRASIL S.A. \\
BANCO BNP PARIBAS BRASIL S.A. \\
BANCO BRADESCO S.A. \\
BANCO CITIBANK S.A. \\
BANCO DE INVESTIMENTOS CREDIT SUISSE (BRASIL) S.A. \\
GOLDMAN SACHS DO BRASIL BANCO MULTIPLO S.A. \\
ITAÚ UNIBANCO S.A. \\
BANCO J.P. MORGAN S.A. \\
BANK OF AMERICA MERRILL LYNCH BANCO MÚLTIPLO S.A. \\
BANCO MORGAN STANLEY S.A. \\
BANCO BTG PACTUAL S.A. \\
BANCO SAFRA S.A. \\
BANCO SANTANDER (BRASIL) S.A. \\
\hline
\end{tabular}

\subsubsection{Limit Order Book}

In this part, we described the Limit Order book (LOB). The LOB was rebuilt considering the best bid and ask quotes, and this day comprises 785,842 observations. Figures 9 to 11 show the bid-ask, the mid quote, and the spread, respectively. Table 8 exhibits the descriptive statistics. 
Table 8: Limit Order Book

\begin{tabular}{ccccc}
\hline DOLZ19 & Best Bid & Best Ask & Middle Quote & Spread \\
\hline Minimum & $4,159.0$ & $4,230.0$ & $4,195.5$ & 0.50 \\
1st Q. & $4,247.5$ & $4,248.0$ & $4,247.7$ & 0.50 \\
Median & $4,255.5$ & $4,256.0$ & $4,255.7$ & 0.50 \\
Mean & $4,255.2$ & $4,255.9$ & $4,255.5$ & 0.77 \\
3rd Q. & $4,263.0$ & $4,263.5$ & $4,263.2$ & 0.50 \\
Max & $4,291.0$ & $4,316.5$ & $4,300.2$ & 86.0 \\
Stand. Dev. & 9.92 & 9.94 & 9.86 & 2.35 \\
Skewness & -0.118 & 0.293 & 0.098 & 17.09 \\
Kurtosis & 0.641 & 0.209 & -0.446 & 346.16 \\
\hline p-value ADF unit root test & 0.617 & 0.617 & 0.614 & 0.01 \\
p-value PP unit root test & 0.691 & 0.691 & 0.691 & 0.01 \\
Sample Size & 785,842 & 785,842 & 785,842 & 785,842 \\
\hline
\end{tabular}

The null hypothesis of unit root is not rejected for bid, ask, and middle quotes in levels. In contrast, the p-value of the spread indicates a stationary series.

\section{CBB FX auctions periods}

Our analysis showed that the CBB FX auctions affected the LOB. In the first programmed auction period, from 09:30:00 a.m. to 9:35:00 a.m., the best bid and ask quotes decreased by $0.16 \%$ in that period, and the spread was constant. As for the second programmed auction, from 11:30 a.m. to 11:40 a.m., the bid-ask quotes were relatively steady.

Regarding the non-programmed auctions, the first one, from 11:03:54 a.m. to 11:08:54 a.m., both quotes fell $0.47 \%$ in that period - the trading prices decreased $0.43 \%$. The spread did not vary but achieved the highest value of 42.5 at 11:05:27 a.m. (85 times than the initial period).

Likewise, in the second non-programmed auction period, from 03:35:06 p.m. to 03:40:06 p.m., the best bid and ask quotes decreased $0.71 \%$ - relative to $-0.65 \%$ trading price.

It is worth mentioning that the mid quote had the most significant negative variation $(-1.4 \%)$ at 03:38:42.678 p.m., and the spread registered a maximum of 86 at 03:39:12.999 p.m., which is also the maximum whole day. During this period, the DOLZ19 trading process halted, but market participants sent orders to the LOB. 


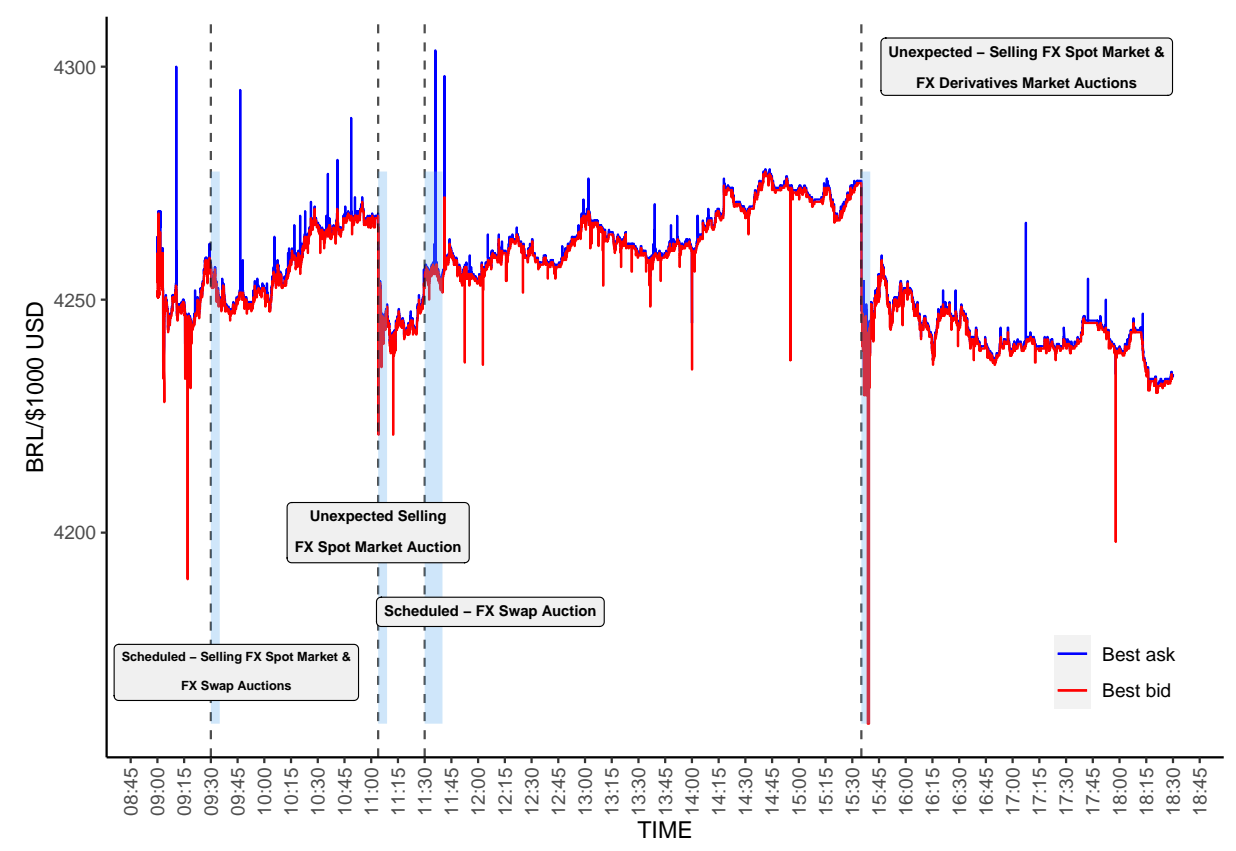

Figure 9: Best bid and Ask quotes per second

Source: B3 - Author's own calculations

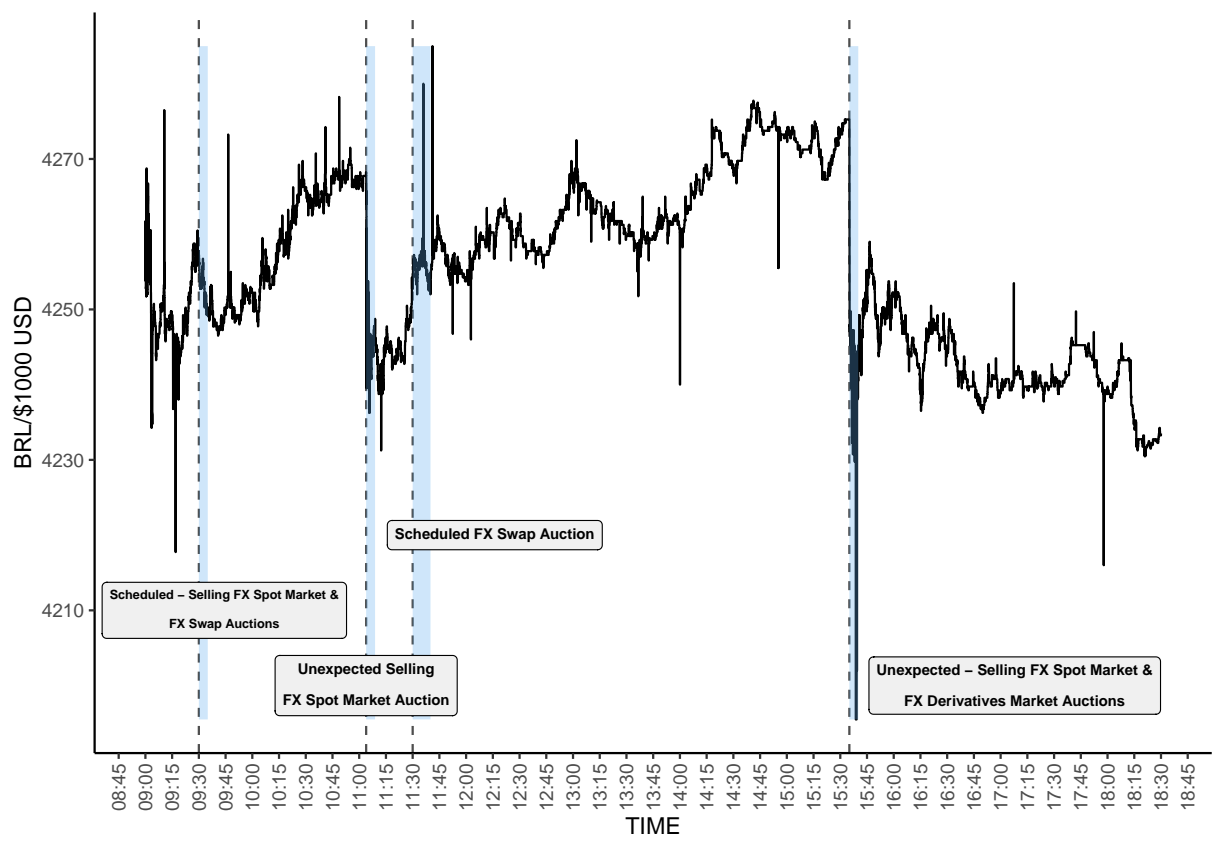

Figure 10: Mid-Quote per second

Source: B3 - Author's own calculations 


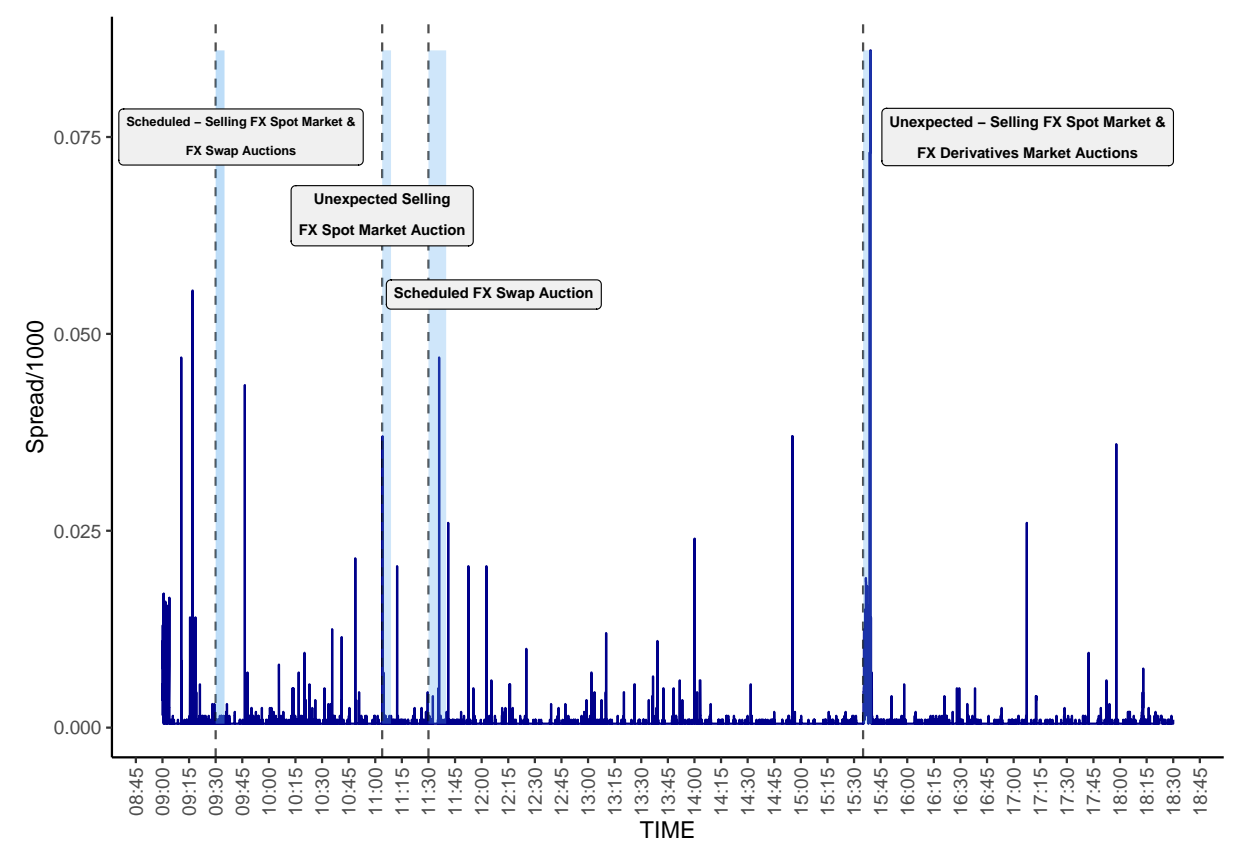

Figure 11: Spread per second

Source: B3 - Author's own calculations

\subsubsection{Returns}

On that day, the returns, measured as the difference between the natural logarithm of trading prices and in basis points, presented an average approximately to zero, with a distribution characterized by left asymmetry and fat tails. The lowest return was at 03:40:04 p.m., which was the first trade after reopening the DOLZ19 trading process.

It is worth mentioning that, in the unexpected auction periods, the returns and squared returns presented the most significant changes - mainly in the second non-programmed intervention. Table 9 shows the descriptive statistics of the returns and the squared returns. Figures 12 and 13 illustrate the returns and squared returns, respectively.

In the first non-programmed auction, the average returns were significantly higher than the daily average. The ratio between the auction average return and the average daily return was 28.2 and 0.6 to the average squared return. As for the second non-programmed auction, the ratio return was 89.7 and 5.3 to ratio squared returns. 
Table 9: Return and Squared Returns

\begin{tabular}{|c|c|c|c|c|c|c|}
\hline \multirow{2}{*}{$\begin{array}{c}\text { Basis points } \\
\text { DOLZ19 }\end{array}$} & \multicolumn{2}{|r|}{ All day } & \multicolumn{2}{|c|}{$\begin{array}{c}\text { 09:30:00 a.m. - 09:35:00 a.m. } \\
\text { Auction Period }\end{array}$} & \multicolumn{2}{|c|}{$\begin{array}{l}\text { 11:03:54 a.m. - 11:08:54 a.m. } \\
\text { Unexp. Auction Period }\end{array}$} \\
\hline & Return & Squared Return & Return & Squared Return & Return & Squared Return \\
\hline Minimum & -15.293 & 0.000 & -2.352 & 0.000 & -8.232 & 0.000 \\
\hline 1st Q. & 0.000 & 0.000 & 0.000 & 0.000 & 0.000 & 0.000 \\
\hline Median & 0.000 & 0.000 & 0.000 & 0.000 & 0.000 & 0.000 \\
\hline Mean & -0.000 & 0.380 & -0.017 & 0.216 & -0.008 & 0.575 \\
\hline 3rd Q. & 0.000 & 0.000 & 0.000 & 0.000 & 0.000 & 0.000 \\
\hline $\operatorname{Max}$ & 16.391 & 268.682 & 2.350 & 5.532 & 5.900 & 67.764 \\
\hline Stand. Dev. & 0.616 & 2.625 & 0.465 & 0.589 & 0.759 & 2.044 \\
\hline Skewenss & 0.222 & 57.345 & -0.124 & 4.065 & -0.189 & 14.042 \\
\hline Kurtosis & 45.70 & $4,596.54$ & 5.391 & 26.39 & 10.596 & 327.90 \\
\hline Sample Size & 62,665 & 62,665 & 970 & 970 & 5,602 & 5,602 \\
\hline
\end{tabular}

\begin{tabular}{|c|c|c|c|c|}
\hline \multirow{2}{*}{$\begin{array}{c}\text { Basis points } \\
\text { DOLZ19 }\end{array}$} & \multicolumn{2}{|c|}{$\begin{array}{c}\text { 11:30:00 a.m. - 11:40:00 a.m. } \\
\text { Auction Period }\end{array}$} & \multicolumn{2}{|c|}{$\begin{array}{c}\text { 03:35:06 p.m. - 03:40:06 p.m. } \\
\text { Unexp. Auction Period }\end{array}$} \\
\hline & Return & Squared Return & Return & Squared Return \\
\hline Minimum & -2.351 & 0.000 & 0.000 & 0.000 \\
\hline 1st Q. & 0.000 & 0.000 & -15.293 & 0.000 \\
\hline Median & 0.000 & 0.000 & 0.000 & 0.000 \\
\hline Mean & 0.000 & 0.251 & -0.054 & 2.037 \\
\hline 3rd Q. & 0.000 & 0.000 & 0.000 & 0.000 \\
\hline $\operatorname{Max}$ & 2.351 & 5.528 & 16.391 & 268.682 \\
\hline Stand. Dev. & 0.501 & 0.656 & 1.427 & 16.255 \\
\hline Skewenss & 0.035 & 4.070 & 0.951 & 11.637 \\
\hline Kurtosis & 4.80 & 25.08 & 61.950 & 152.10 \\
\hline Sample Size & 2,037 & 2,037 & 1,217 & 1,217 \\
\hline
\end{tabular}

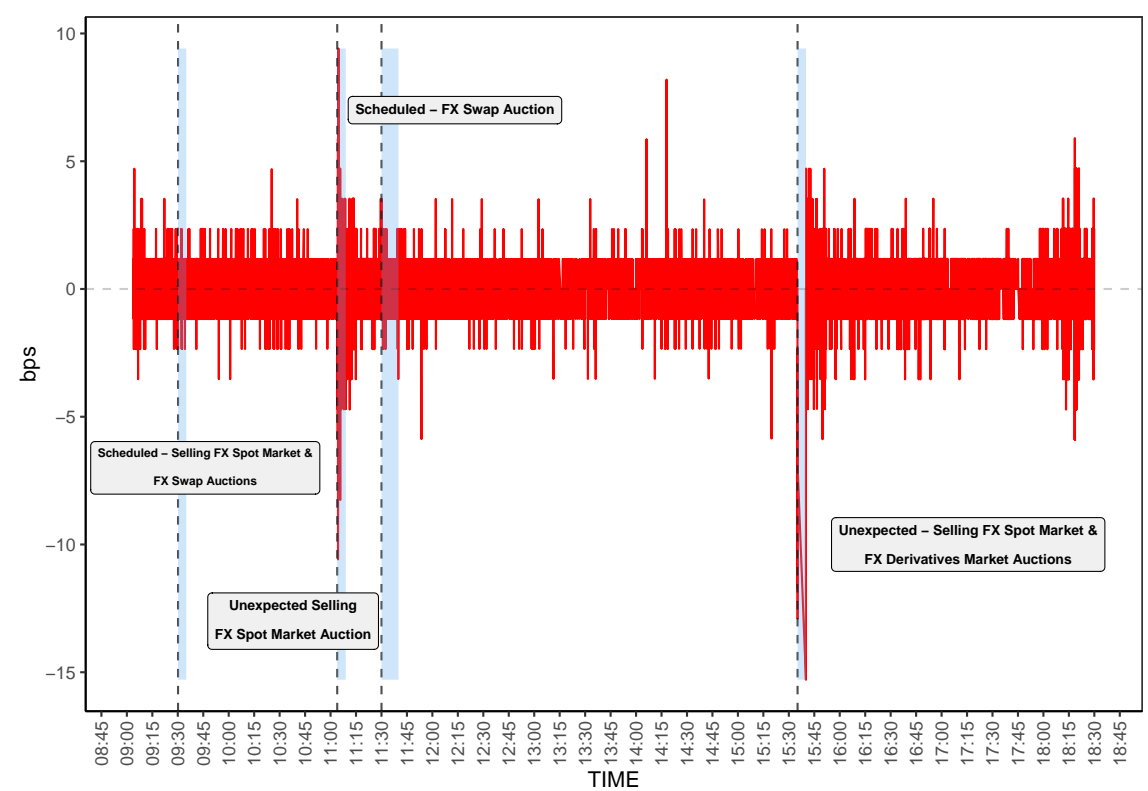

Figure 12: Return per second

Source: B3 - Author's own calculations 


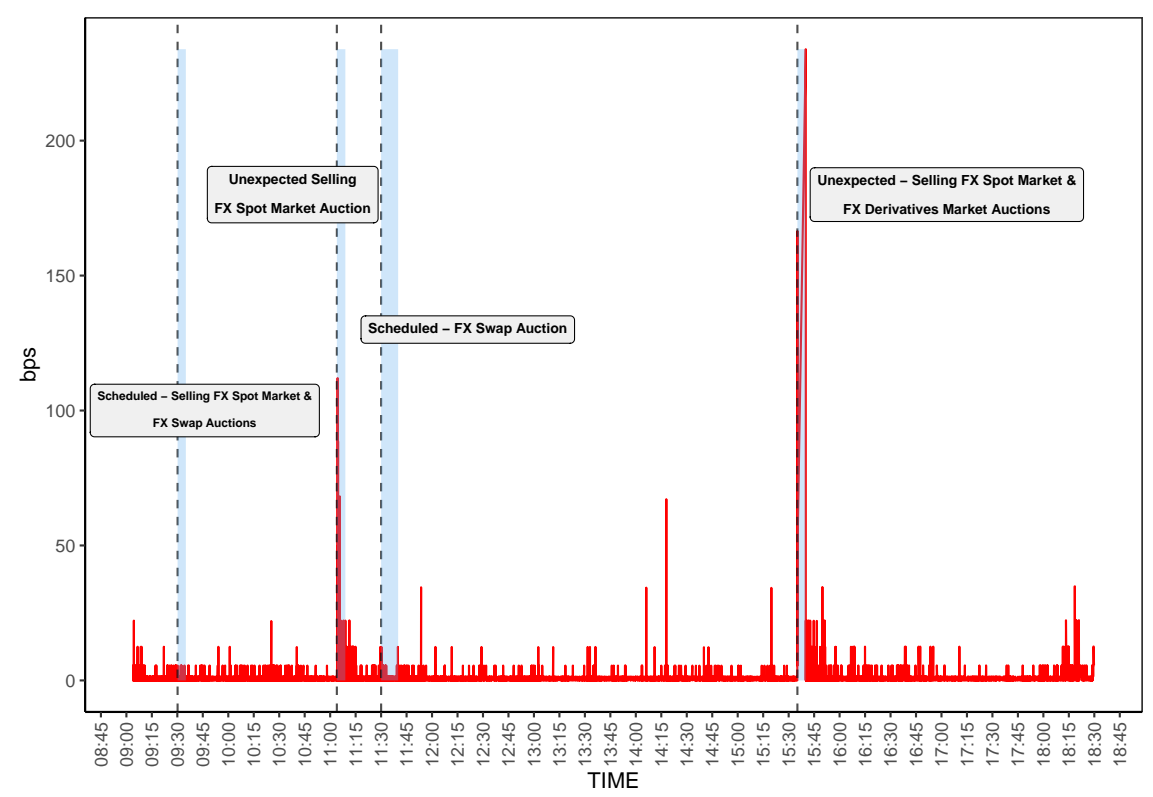

Figure 13: Squared Return per second

Source: B3 - Author's own calculations

In summary, this section described the DOLZ19 trading process on November $26^{\text {th }}$, 2019. From trading price to LOB, it is clear that the CBB FX auctions influenced that day. Mainly the unexpected ones. There were significant changes in returns, volume, order flow, and bid-ask quotes in those periods. Moreover, we could also identify the market participants and how they traded along the day.

\section{$5 \quad$ Liquidity Results}

In this section, our purpose is to present the liquidity results. It comprises the relative spread, the illiquidity ratios, the price impact and return reversal.

\subsection{Relative Spread}

The relative bid-ask spread, in basis points, comprises 785,842 observations and presented a daily average of 1.822 , with a minimum of 1.169 and a maximum of 204.664 . Table 10 presents the descriptive statistics. Figure 14 shows the relative bid-ask spread during the day.

Despite the relative spread average in the auction periods presented no substantial changes close to the daily average, except for the last CBB auction, there were significant 
peaks during the auction periods, reflecting low liquidity in the market. The most notable summit and, consequently, the maximum values of the sample occurred between 03:38:42 p.m. and 03:39:23 p.m., a period characterized by the second non-programmed CBB FX selling auction and by a halted DOLZ19 trading process. It is important to emphasize that increase was due to the rise in the spread. Table 10 also presents the descriptive statistics for the auction periods.

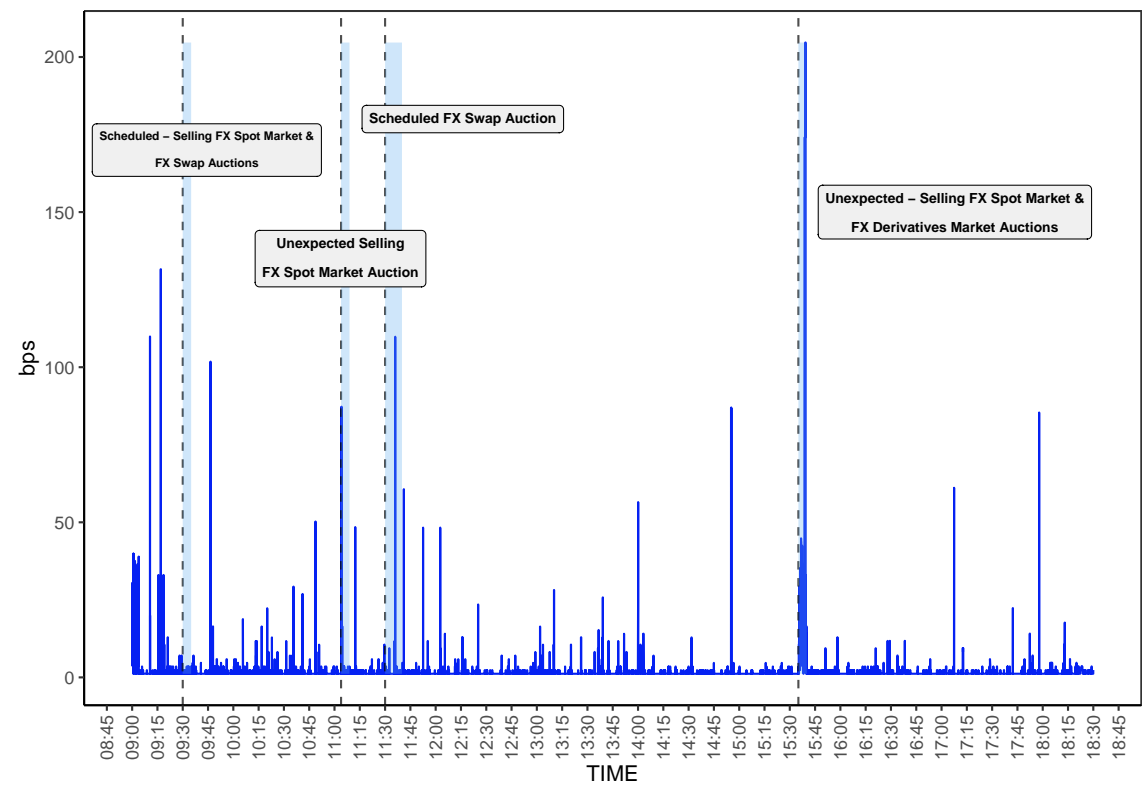

Figure 14: Relative Spread per second

Source: B3 - Author's own calculations

\section{$5.2 \quad$ Illiquidity Indexes}

The illiquidity indexes results, the $I_{k}^{\text {Time }}$ and the $I_{k}^{\text {Volume }}$, are scaled by bps $/ \$ 1 M$. Table 10 presents the results, and figures 15 and 16 show their respective graphs.

The illiquidity index $I_{k}^{\text {Time }}$ built on a fixed one-minute interval showed the highest illiquidity levels at the end of the day. However, it did not present significant evidence as other liquidity indexes.

Nevertheless, as mentioned before, Hasbrouck and Levich (2019) argued that $I_{k}^{\text {Time }}$ presents some problems, and $I_{k}^{\text {Volume }}$ index is preferred. 


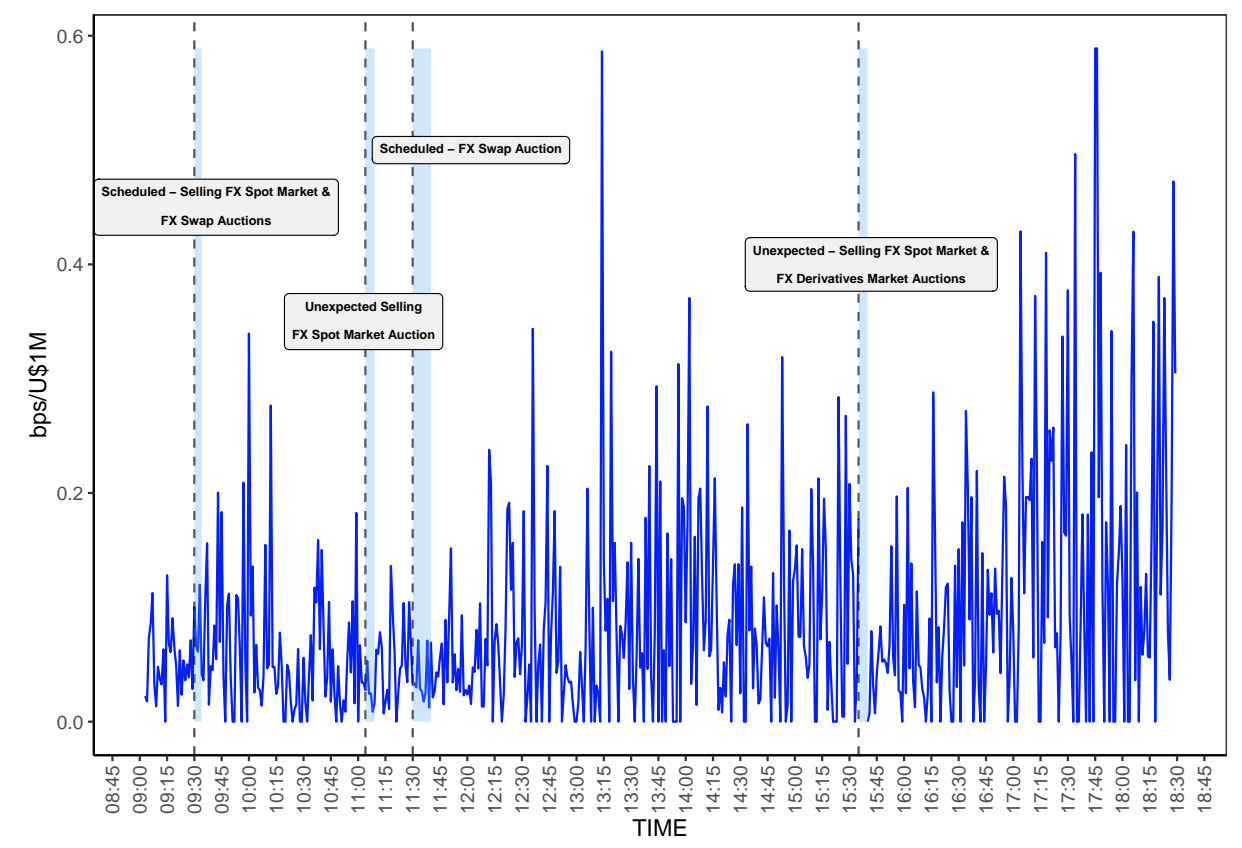

Figure 15: Illiquid Index: One-minute interval

Source: B3 - Author's own calculations

The second illiquidity index $I_{k}^{\text {volume }}$, built on USD $\$ 100 \mathrm{M}$ intervals - in basis points. These results were closer to the relative spread and more informative than the $I_{k}^{\text {Time }}$. Table 10 presents the descriptive statistics for the whole day and auction periods.

The highest sample values, and hence, the most illiquidity periods, were at 11:05:37 a.m., 03:35:13 p.m., and 03:40:04 p.m., which all corresponded to the non-programmed CBB FX intervention auctions periods. 


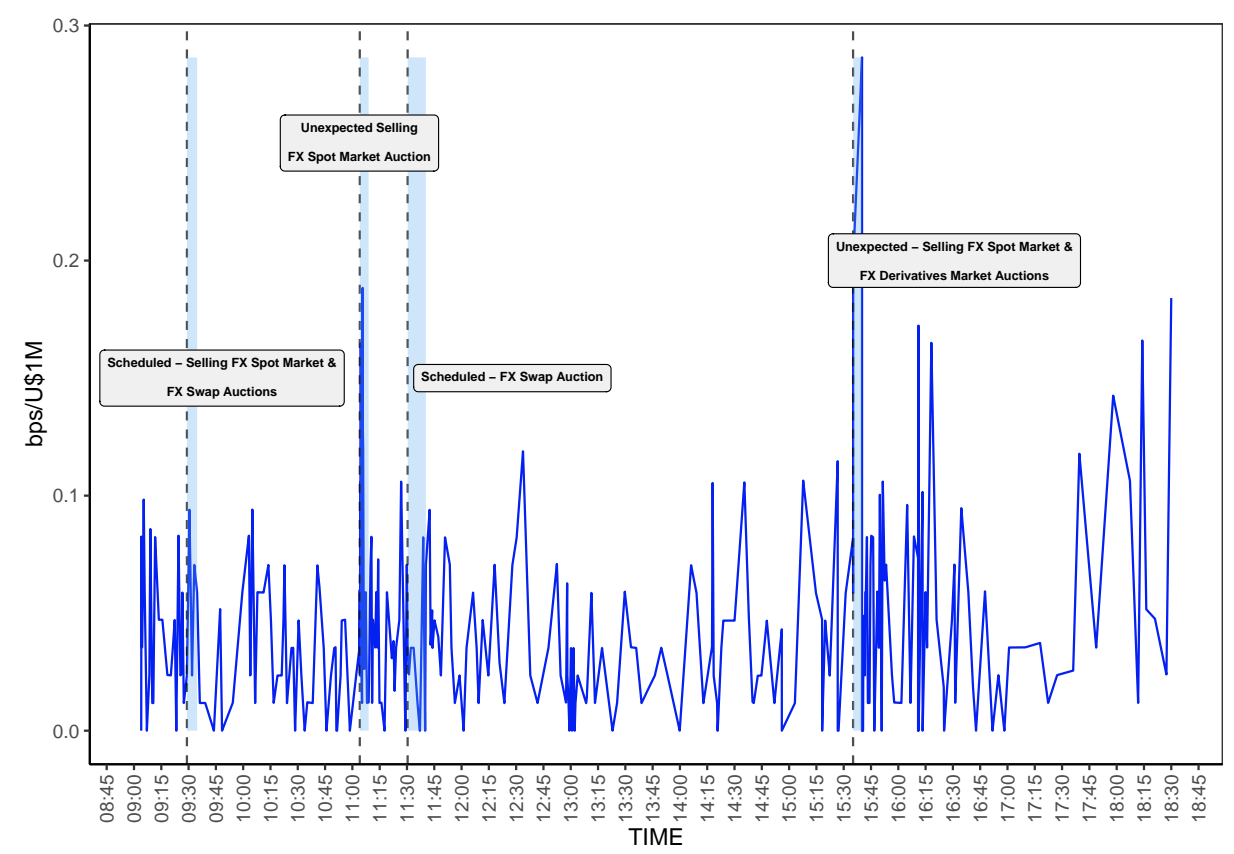

Figure 16: Illiquid Index: Volume

Source: B3 - Author's own calculations 
Table 10: Liquidity Indexes

\begin{tabular}{cccc|ccc|ccc}
\multicolumn{5}{c}{$\begin{array}{c}\text { 09:00:00 a.m. - 06:30:00 p.m. } \\
\text { Whole day }\end{array}$} & \multicolumn{2}{c|}{$\begin{array}{c}\text { 09:30:00 a.m. - 09:35:00 a.m. } \\
\text { Auction Period }\end{array}$} & \multicolumn{3}{c}{ 11:03:54 a.m. - 11:08:54 a.m. } \\
Unexp. Auction Period
\end{tabular}

\begin{tabular}{l|l} 
11:30:00 a.m. - 11:40:00 a.m. & 03:35:06 p.m. - 03:40:06 p.m.
\end{tabular}

\begin{tabular}{|c|c|c|c|c|c|c|c|}
\hline & \multicolumn{3}{|c|}{$\begin{array}{c}\text { 11:30:00 a.m. - 11:40:00 a.m. } \\
\text { Auction Period }\end{array}$} & \multicolumn{3}{|c|}{$\begin{array}{c}\text { 03:35:06 p.m. - 03:40:06 p.m. } \\
\text { Unexp. Auction Period }\end{array}$} & \\
\hline DOLZ19 & Relative Spread & $I^{\text {Time }}$ & $I^{V o l}$ & Relative Spread & $I^{\text {Time }}$ & $I^{V o l}$ & \\
\hline Minimum & 1.174 & 0.012 & 0.000 & 1.169 & 0.177 & 0.0000 & \\
\hline 1st Q. & 1.175 & 0.025 & 0.000 & 1.173 & 0.177 & 0.0000 & \\
\hline Median & 1.175 & 0.029 & 0.024 & 1.175 & 0.177 & 0.059 & \\
\hline Mean & 1.865 & 0.035 & 0.025 & 6.274 & 0.177 & 0.089 & \\
\hline 3rd Q. & 1.175 & 0.033 & 0.035 & 3.518 & 0.177 & 0.141 & \\
\hline Max & 109.813 & 0.071 & 0.082 & 204.664 & 0.177 & 0.286 & \\
\hline Stand. Dev. & 6.292 & 0.020 & 0.027 & 18.794 & - & 0.112 & \\
\hline Skewenss & 14.452 & 1.097 & 1.010 & 7.897 & - & 0.859 & \\
\hline Kurtosis & 223.658 & -0.158 & 0.382 & 69.626 & - & -0.759 & \\
\hline Sample Size & 29,287 & 10 & 9 & 8,110 & 1 & 7 & \\
\hline
\end{tabular}




\subsection{Price Impact and Return Reversal}

The price impact and the return reversal were estimated based on equation (3), using returns in basis point, order flow in billions, and lagged order flow. The equation was estimated considering data per second, the OLS method robust to heteroscedasticity-consistent (HC) covariance estimators.

More lags were added, but neither was statistically significant. Table 11 illustrates the analyses for the whole day, 09:00 a.m. until 06:30 p.m. We divided the sample by hour and recalculated the model.

The auctions periods were at 09:00:00 a.m.- 09:59:59 a.m., 11:00:00 a.m.- 11:59:59 a.m. and 03:00:00 p.m. - 03:59:59 p.m. samples.

Table 11: Price Impact and Return Reversal

\begin{tabular}{|c|c|c|c|c|c|}
\hline Return $_{t}$ & Intercept & Return $_{t-1}$ & $\begin{array}{c}\text { OrderFlow } \\
\text { (Price impact) }\end{array}$ & OrderFlow $w_{t-1}$ & $R^{2}$ \\
\hline $\begin{array}{c}\text { 09:00 a.m. - 06:30 p.m. } \\
\text { Whole day }\end{array}$ & -0.012 & $-0.177 * * *$ & $153.221 * * *$ & $30.927 *$ & 0.26 \\
\hline 09:00 a.m. - 10:00 a.m. & 0.006 & $-0.199 * * *$ & $130.481 * * *$ & $28.455 * * *$ & 0.24 \\
\hline 10:00 a.m. - 11:00 a.m. & -0.006 & $-0.222 * * *$ & $154.908 * * *$ & $30.171 * * *$ & 0.31 \\
\hline 11:00 a.m. - 12:00 p.m. & 0.015 & $-0.107 * *$ & $168.827 * * *$ & 6.156 & 0.36 \\
\hline 12:00 p.m. - 01:00 p.m. & -0.014 & $-0.201 * * *$ & $147.912 * * *$ & 10.517 & 0.25 \\
\hline 01:00 p.m. - 02:00 p.m. & $-0.050^{*}$ & $-0.181 * * *$ & $141.553 * * *$ & 14.522 & 0.28 \\
\hline 02:00 p.m. - 03:00 p.m. & 0.013 & $-0.344 * * *$ & $167.508 * * *$ & $35.677 * * *$ & 0.39 \\
\hline 03:00 p.m. - 04:00 p.m. & -0.044 & -0.018 & $122.565 *$ & 57.420 & 0.19 \\
\hline 04:00 p.m. - 05:00 p.m. & 0.003 & $-0.173 * * *$ & 216.396 *** & 9.650 & 0.30 \\
\hline 05:00 p.m. - 06:00 p.m. & -0.042 & $-0.251 * * *$ & $245.823 * * *$ & 30.869 & 0.23 \\
\hline 06:00 p.m. - 06:30 p.m. & -0.030 & $-0.502 * * *$ & $222.862 * * *$ & $103.543 *$ & 0.34 \\
\hline
\end{tabular}

All the parameters were statistically significant in the whole sample at $10 \%$, and the regression presented an $R^{2}$ of $26 \%$. The price impact was 153.22 , which means that a positive one billion order flow is associated with a $1.53 \%$ currency (BRL) depreciation. ${ }^{10}$

\footnotetext{
${ }^{10}$ Ferreira et al. (2019) found a statistically significant price impact of 100.49 with a $R^{2}$ of $17.72 \%$ in the Brazilian FX futures market between October 2011 to December 2013. Also, between 2006 and 2007, Ventura and Garcia (2012), found that a positive one billion order flow should impact the currency (BRL) in $0.9 \%$ for 1-minute aggregation with a $R^{2}$ of $5,3 \%$, and an impact of $0,2 \%$ with $R^{2}$ of $18.4 \%$ on daily frequency data.
} 
For the hourly samples, the contemporaneous order flow was statistically significant at $10 \%$. For almost all estimations, the lagged return was statistically significant, in contrast to the lagged order flow. The price impact parameters did not show a daily pattern, but they were relatively higher at the beginning and the closing of the trading day.

These results suggest that the market liquidity was lower at the opening and the ending trade period. Laurini et al. (2008) showed a tendency of spread increase in the beginning and the closing trade period in the Brazil FX market - the increase in the spread reflects a decreased in the liquidity.

At the auctions periods, in the 11:00 a.m. to 12:00 p.m. interval, which comprises the first unexpected auction, the liquidity decreased. This result is in line with other illiquidity measures. However, from 03:00 p.m. to 04:00 p.m, which comprises the second unexpected auction, the liquidity increased significantly.

These results may be influenced by the structure breaks at the non-programmed auctions. Then, we introduced one-minute dummy variables, where it assumes value one at the auction periods. Given the 5-minute auction periods, we included five dummies in the first unexpected auction and two dummy variables in the second one, two because the market halted for almost 5 minutes. Table 12 shows the results, and to reduce the space, it presents only the main variables. The dummy $d .11 .04$ and $d .03 .35$ are the 11:04 a.m. and the 03:35 p.m. intervals, respectively.

Table 12: Price Impact and Return Reversal II

\begin{tabular}{|c|c|c|}
\hline & \multicolumn{2}{|c|}{ Dependent variable: } \\
\hline & \multicolumn{2}{|c|}{ Return $_{t}$} \\
\hline & $\begin{array}{l}\text { 11:00 a.m. to 12:00 a.m. } \\
\text { (1) }\end{array}$ & $\begin{array}{l}\text { 03:00 p.m. to } 04: 00 \text { p.m. } \\
\text { (2) }\end{array}$ \\
\hline Return $_{t-1}$ & $\begin{array}{c}-0.116^{* * *} \\
(0.035)\end{array}$ & $\begin{array}{l}-0.024 \\
(0.105)\end{array}$ \\
\hline OrderFlow & $\begin{array}{c}170.172^{* * *} \\
(17.150)\end{array}$ & $\begin{array}{c}178.569^{* * *} \\
(26.095)\end{array}$ \\
\hline OrderFlow $*$ d.11.04 & $\begin{array}{l}87.349^{* *} \\
(41.257)\end{array}$ & \\
\hline d.03.35 & & $\begin{array}{c}-5.949^{* * *} \\
(2.230)\end{array}$ \\
\hline Observations & 1,708 & 1,201 \\
\hline $\mathrm{R}^{2}$ & 0.380 & 0.302 \\
\hline Adjusted $\mathrm{R}^{2}$ & 0.375 & 0.297 \\
\hline Residual Std. Error & $0.997(\mathrm{df}=1694)$ & $1.182(\mathrm{df}=1193)$ \\
\hline F Statistic & $79.716^{* * *}(\mathrm{df}=13 ; 1694)$ & $73.589^{* * *}(\mathrm{df}=7 ; 1193)$ \\
\hline
\end{tabular}


First, at the 11:00 a.m to 12:00 a.m. period, the price impact increase relative to the first estimation, i.e., the liquidity decreased. For the 03:00 p.m. to 04:00 p.m. interval, the price impact rose significantly with the dummy variable, in line with the other illiquidity measures.

With all these liquidity results, it is possible that some traders were cautiously incorporating new information about the foreign exchange market - CBB intervention auctions -, and they were transmitting it into prices to cover potential losses.

Then, the first contribution of this research is that the market illiquidity on November $26^{\text {th }}, 2019$, were related to the CBB FX intervention auctions periods, mainly in the unexpected ones.

All these section results show that market liquidity varied along the day and also in the auctions periods. But, it is important to note that some intraday periodicity may influence our calculations. And, for a general statement, this analysis should be expanded to other days.

\section{Price Discovery Results}

This section analyzes the effects of CBB's foreign exchange intervention auctions on the contribution of the bid and ask quotes to price discovery in the Brazilian foreign exchange futures market on November $26^{\text {th }}, 2019$.

This study uses the most common price discovery metrics, the Information share (IS) and the Component Share (CS). Also, the price discovery metrics rely on the LOB data and the natural logarithm of the bid and ask quotes per second. Our research also investigates the price discovery on hourly samples to understand the dynamics during the day and see if the CBB FX auctions contribute to those variations.

According to the methodology presented in section 3 , it is necessary to investigate if the bid and ask quotes have a long-term relationship, then estimate the VECM, and subsequently, those price discovery metrics.

For a long-term relationship, the Johansen cointegration test was applied. There were used 33 lags and selected by the Schwarz information criterion. The test suggests at least one cointegration relation between the bid and ask quotes per second, reflecting a long-term relationship. Table 13 shows the results of the Johansen cointegration test.

However, Laurini et al. (2008) argued that this test is valid for the normal distribution 
of the residual and in the absence of structural breaks. A possible violation may affect the power and the critical values of the test. In our case, both hypotheses are violated.

First, the skewness and kurtosis of both log quote variables indicate a non-gaussian distribution. Moreover, due to the FX non-programmed auctions, the bid and ask quotes exhibited at least two structural breaks.

Laurini et al. (2008) presented an economic explanation for the cointegration vector existence between the bid and ask quotes. There would be systematic arbitrage opportunities if there were some disequilibrium between them, representing a non-stationary spread. Then, we do not reject the hypothesis of at least one cointegration vector, despite the possible problems in the power of the test.

Table 13: Johansen co-integration test

Values of test-statistic and critical values of test

\begin{tabular}{lrrrr}
\hline \multicolumn{1}{c}{ Trace test statistic } & test & 10 pct & 5 pct & 1 pct \\
$\mathrm{r}<=1$ & 4.00 & 7.52 & 9.24 & 12.97 \\
$\mathrm{r}=0$ & 481.76 & 17.85 & 19.96 & 24.60 \\
\hline Maximum eigenvalue test statistic & test & $10 \mathrm{pct}$ & $5 \mathrm{pct}$ & $1 \mathrm{pct}$ \\
$\mathrm{r}<=1$ & 4.00 & 7.52 & 9.24 & 12.97 \\
$\mathrm{r}=0$ & 477.76 & 13.75 & 15.67 & 20.20 \\
\hline $\mathrm{r}$ is the number of
\end{tabular}

is the number of cointegrating relations;

The null hypothesis of $r=0$ means that there is no cointegration at all A $r>0$ implies a cointegrating between two or possibly variables.

In the second step, it was estimated VECM based on equation (4). Table 14 presents the VECM results. Moreover, it shows the cointegration relation, the error correction term, and the short-term parameters. The values in parentheses are the standard errors, and in the brackets are the p-values.

Finally, it is possible to construct the IS and CS metrics. Firstly, our price discovery result comprises the whole open market period, 09:00 a.m. to 06:30 p.m. Then, the IS and CS are estimated by hourly samples. Table 15 shows the results.

For the open market period, with more net-buys in the market, ask quotes (sell-side) presented a $94.7 \%$ IS value and $92.5 \%$ CS value, which means that the sell-side contributed to $94.7 \%$ of the variance and $92.5 \%$ in share to the efficient price, i.e., the sell-side is leader side of the market.

These results are consistent with Pascual and Pascual-Fuster (2014), Chen and Gau (2014) and Chen and Gau (2015), where they argued that the more net-buys have a greater impact on the ask price than on the bid price, contributing to sell-side market leadership ${ }^{11}$.

\footnotetext{
${ }^{11}(\ldots)$ when the Japanese authority buys USD and sells JPY, the USD sellers update their ask prices more
} 
Table 14: VECM Results

\begin{tabular}{|c|c|c|}
\hline \multicolumn{3}{|c|}{ Long-term Dynamic } \\
\hline \multicolumn{3}{|c|}{ Cointegration Equation } \\
\hline$\Delta \log (\operatorname{ask}(-1))$ & \multicolumn{2}{|c|}{1.0000} \\
\hline$\Delta \log (\operatorname{bid}(-1))$ & \multicolumn{2}{|c|}{-0.9853} \\
\hline Constant & \multicolumn{2}{|c|}{-0.1221} \\
\hline \multicolumn{3}{|c|}{ Error Correction Term } \\
\hline \multirow{4}{*}{ ECT } & $\Delta \log ($ ask $)$ & $\Delta \log ($ bid $)$ \\
\hline & -0.0058 & 0.0715 \\
\hline & $(0.0026)$ & $(0.0034)$ \\
\hline & {$[0.0278]$} & {$[<2 \mathrm{e}-16]$} \\
\hline \multicolumn{3}{|c|}{ Short-term Dynamic* } \\
\hline \multirow{3}{*}{$\Delta \log (\operatorname{ask}(-1))$} & $\Delta \log ($ ask $)$ & $\Delta \log ($ bid $)$ \\
\hline & -0.4104 & -0.0088 \\
\hline & $(0.0065)$ & $(0.0084)$ \\
\hline \multirow{4}{*}{$\Delta \log (\operatorname{bid}(-1))$} & {$[<2 \mathrm{e}-16]$} & {$[0.2925]$} \\
\hline & 0.0361 & -0.1060 \\
\hline & $(0.0050)$ & $(0.0065)$ \\
\hline & {$[7.45 \mathrm{e}-13]$} & {$[<2 \mathrm{e}-16]$} \\
\hline \multirow[t]{2}{*}{$\Delta \log (\operatorname{ask}(-2))$} & -0.2833 & -0.0297 \\
\hline & $(0.0069)$ & $(0.0089)$ \\
\hline & {$[<2 \mathrm{e}-16]$} & {$[0.0009]$} \\
\hline \multirow[t]{3}{*}{$\Delta \log (\operatorname{bid}(-2))$} & 0.0392 & -0.0704 \\
\hline & $(0.0049)$ & $(0.0064)$ \\
\hline & {$[3.10 \mathrm{e}-15]$} & {$[<2 \mathrm{e}-16]$} \\
\hline
\end{tabular}

It also sheds light on the order flow's importance to explain each side's contribution to price formation.

Then, these results suggest that exists some information asymmetry in the Brazilian FX futures market on November $26^{\text {th }}, 2019$, with ask quotes (sell-side) prevailing over bid quotes (buy-side). These results are corroborated by Laurini et al. (2008), where the authors, with a nonparametric test for the Markov property, found asymmetry information in the Brazilian foreign exchange market.

In the following step, we estimated the IS and CS metrics for ten samples and found that the bid and ask quotes (buy-sell sides) contribution to price discovery changed along the day. Except for the second sample of the day, in more net-buy periods, the ask quotes had more impact on price formation than bid quotes, and in net-sells samples otherwise.

Considering samples that comprise auctions periods, the first sample (09:00:00 a.m.09:59:59 a.m.), characterized by more net-buys and only programmed auctions, the sell-side had the market leadership.

In the 11:00:00 a.m.- 11:59:59 a.m. sample, which presented more net-sells and quickly to the new information, and hence, the informational efficiency of ask quotes increases. 
two auctions - non-programmed and programmed - the buy-side contributed more to price discovery than the sell-side. These results are in line with the literature.

The relevant point is that the selling pressure was mainly in the auction periods, in the unexpected auction. As described before, the Dealers-14 - specially BTG Pactual, Santander, and Itau - had the higher selling volume in that period. Then, given this selling pressure, the DOLZ19 buyers probably reacted to this intervention news more quickly, and hence the bid quote contribution to price formation.

The 03:00:00 p.m. - 03:59:59 p.m. sample comprises the second unexpected auction with more net-buys, the ask quote IS value was $98.0 \%$ and CS value of $92.7 \%$, indicating the sell-side leadership in that period. At first, the CBB unexpected auction did not influence the price discovery results. Nevertheless, if we get more closely, there was more DOLZ19 buying pressure until the CBB FX selling intervention auction. Because of the small selling pressure window, the price discovery metrics probably did not get this intervention shock.

However, as described before, after the second unexpected CBB FX intervention auction, the DOLZ19 started a downward trend until the end of the day. In the following sample 04:00:00 p.m.- 04:59:59 p.m., which had more selling pressure, the buy-side contributed more to price discovery than the sell-side.

The IS and CS results are related to the CBB FX unexpected auction and order flow. In this case, the main participants that influence the net-sells were BTG and Santander, both Dealers-14.

Then, the third result of this study is that, on November $26^{\text {th }}, 2019$, the contribution of bid quote (buy-side) and ask quote (buy-side) to price discovery in the Brazilian futures markets varied along the day. The factor that impacted those changes was the presence of CBB FX selling intervention auctions, and consequently, the negative order flow, as already pointed out by Pascual and Pascual-Fuster (2014), Chen and Gau (2014) and Chen and Gau (2015).

These results indicate that the transmission of information to prices is not equal among the market participants. Institutional frameworks and asymmetric information affected how prices were discovered. These metrics and the detailed trading description enabled us to understand information flow between agents and markets.

Some issues should be pointed out. First, there are two structural breaks in our database, given the CBB FX non-programmed auctions, which could affect the VECM and the IS and CS estimations. Moreover, some intraday periodicity could also affect our calculations. 
Lastly, these empirical conclusions represent a short snapshot from a specific trading day. Other similar days would be necessary for a general assertion and different methodologies to capture structure breaks and intraday periodicity.

Table 15: Price Discovery

\begin{tabular}{|c|c|c|c|c|}
\hline Samples & $\begin{array}{c}\text { Order flow } \\
\text { (USD billions) }\end{array}$ & Quotes & IS & CS \\
\hline \multirow{2}{*}{$\begin{array}{c}\text { 09:00:00 a.m. - 06:30:00 p.m } \\
\text { Whole Day }\end{array}$} & \multirow{2}{*}{0.529} & Ask & $94.7 \%$ & $92.5 \%$ \\
\hline & & Bid & $5.3 \%$ & $7.5 \%$ \\
\hline \multirow{2}{*}{ 09:00:00 a.m. - 09:59:59 a.m. } & \multirow{2}{*}{0.051} & Ask & $62.7 \%$ & $57.6 \%$ \\
\hline & & Bid & $37.3 \%$ & $42.4 \%$ \\
\hline \multirow{2}{*}{ 10:00:00 a.m. - 10:59:59 a.m. } & \multirow{2}{*}{0.261} & Ask & $4.0 \%$ & $6.0 \%$ \\
\hline & & Bid & $96.0 \%$ & $94.0 \%$ \\
\hline \multirow{2}{*}{ 11:00:00 a.m. - 11:59:59 a.m. } & \multirow{2}{*}{-0.345} & Ask & $32.9 \%$ & $32.2 \%$ \\
\hline & & Bid & $67.1 \%$ & $67.8 \%$ \\
\hline \multirow{2}{*}{ 12:00:00 p.m. - 12:59:59 p.m. } & \multirow{2}{*}{0.340} & Ask & $85.4 \%$ & $88.2 \%$ \\
\hline & & Bid & $14.6 \%$ & $11.8 \%$ \\
\hline \multirow{2}{*}{ 01:00:00 p.m. - 01:59:59 p.m. } & \multirow{2}{*}{0.142} & Ask & $76.8 \%$ & $73.8 \%$ \\
\hline & & Bid & $23.2 \%$ & $26.2 \%$ \\
\hline \multirow{2}{*}{ 02:00:00 p.m. - 02:59:59 p.m. } & \multirow{2}{*}{0.139} & Ask & $80.4 \%$ & $90.4 \%$ \\
\hline & & Bid & $19.6 \%$ & $9.6 \%$ \\
\hline \multirow{2}{*}{ 03:00:00 p.m. - 03:59:59 p.m. } & \multirow{2}{*}{0.015} & Ask & $98.0 \%$ & $92.7 \%$ \\
\hline & & Bid & $2.0 \%$ & $7.3 \%$ \\
\hline \multirow{2}{*}{ 04:00:00 p.m. - 04:59:59 p.m. } & \multirow{2}{*}{-0.160} & Ask & $43.3 \%$ & $38.7 \%$ \\
\hline & & Bid & $56.7 \%$ & $61.3 \%$ \\
\hline \multirow{2}{*}{ 05:00:00 p.m - 05:59:59 p.m. } & \multirow{2}{*}{0.098} & Ask & $69.7 \%$ & $71.2 \%$ \\
\hline & & Bid & $30.3 \%$ & $28.8 \%$ \\
\hline \multirow{2}{*}{ 06:00:00 p.m - 06:29:59 p.m. } & \multirow{2}{*}{-0.012} & Ask & $7.5 \%$ & $2.1 \%$ \\
\hline & & Bid & $92.5 \%$ & $97.9 \%$ \\
\hline
\end{tabular}

\section{Conclusion}

This research empirically studies the effects of Brazil's central bank FX intervention auctions on the market liquidity and the contribution of bid and ask quotes to price discovery in the Brazilian FX futures market. The main objective was to investigate how market 
participants incorporated the new information and transmitted it to prices.

Based on high-frequency data, this study examined and described in detail way a specific trading day of the Brazilian foreign exchange futures market, November $26^{\text {th }}, 2019$. This research strategy allowed us to identify the exact moment the CBB auction information arrived and how the market participants reacted.

The first empirical results showed that the most illiquidity periods occurred at the CBB FX intervention auction periods, mainly in the unexpected ones. In those periods, it is possible that market participants were incorporating the new information, and they were passing it on to prices to cover potential losses.

As for the price discovery results, the conclusion is that, on November $26^{\text {th }}, 2019$, the contribution of bid and ask quotes to price discovery was asymmetric in the Brazilian FX futures market. Additionally, on that day, with more net buys in the market, the ask quotes (sell-side) contributed more to price discovery than the bid quotes (buy-side).

In the hourly samples, we found that, in most cases, the sell-side continued to present more contribution to price formation than the buy-side. However, when the CBB intervened in the foreign exchange market, the results changed. Those auctions, mainly the unexpected ones, started a selling movement that affected the price discovery results. In those periods, the buy-side had the leadership of the market.

Therefore, the third result of this study is that, on that day, the contribution of bid quote (buy-side) and ask quote (buy-side) to price discovery in the Brazilian futures markets varied along the day. The factor that impacted those changes was the presence of CBB FX selling intervention auctions.

All these results showed that the transmission of information to prices is not equal among the market participants. Institutional frameworks and asymmetric information affected price formation. These metrics and the detailed trading description enabled us to understand better the price dynamic within the FX intervention scope.

These conclusions are a snapshot of specific trading, and for a general assertion, it would be necessary to analyze other trading days.

\section{References}

Amihud, Y. (2012). Illiquidity and stock returns: cross-section and time-series effects. Journal of Financial Markets 5, 31-56. 
Amihud, Y. and H. Mendelson (1980). Dealership market: market making with inventory. Journal of Financial Economics 8, 31-53.

Baillie, R. T., G. G. Booth, Y. Tse, and T. Zabotina (2002). Price discovery and common factor models. Journal of Financial Markets 5, 309-321.

Barardehi, Y. H., D. Bernhardt, and R. J. Davies (2018). Trade-time measures of liquidity. The Review of Financial Studies 32 (1), 126-179.

Bastos, E. K. X. and P. V. da Silva Fontes (2014). Mercado de câmbio brasileiro, intervenções do banco central e controles de capitais de 1999 a 2012. Ipea: Texto para discussão, 1-92.

Booth, G. G., R. W. So, and Y. Tse (1999). Price discovery in the german equity index derivatives markets. Journal of Futures Markets 19 (6), 619-643.

CBB (2019). O mercado de câmbio brasileiro e o desenvolvimento do mercado de derivativos cambiais. Estudos especiais do Banco Central 41, 1-7.

Chen, Y.-L. and Y.-F. Gau (2014). Asymmetric responses of ask and bid quotes to information in the foreign exchange market. Journal of Banking \& Finance 38, 194-204.

Chen, Y.-L. and Y.-F. Gau (2015). Foreign exchange market intervention and price discovery. Journal of The Japanese and International Economies 38, 214-227.

Chu, Q. C., W. liang Gideon Hsieh, and Y. Tse (1999). Price discovery on the s\&p 500 index markets: An analysis of spot index, index futures, and spdrs. International Review of Financial Analysis 8 (1), 21-34.

de Boyrie, M. E., I. Pavlova, and A. M. Parhizgari (2012). Price discovery in currency markets: Evidence from three emerging markets. International Journal of Economics and Finance 4 (12), 61-75.

de Jong, F. (2002). Measures of contributions to price discovery: a comparison. Journal of Financial Market 5 (3), 323-327.

de Oliveira, F. N. and A. Plaga (2011). Eficácia das intervenções do banco central do brasil sobre a volatilidade condicional da taxa de câmbio nominal. Revista Brasileira de Economia 65 (1), 71-92.

Dominguez, K. M. (2003). The market microstructure of central bank intervention. Journal of International Economics 59 (1), 25-45. 
Dominguez, K. M. (2006). When do central bank interventions influence intra-daily and longer-term exchange rate movements? Journal of International Money and Finance 25 (7), 1051-1071.

Dufour, A. and R. F. Engle (2000). Time and the price impact of a trade. The Journal of Finance 55(6), 2467-2498.

Easley, D. and M. O'Hara (1992). Time and the process of security price adjustment. The Journal of Finance 47(2), 577-605.

Engle, R. F. and C. W. J. Granger (1987). Co-integration and error correction: Representation, estimation, and testing. Econometrica 55 (2), 251-276.

Engle, R. F. and A. J. Patton (2004). Impacts of trades in an error-correction model of quote prices. Journal of Financial Markets 7 (1), 1-25.

Escribano, A. and R. Pascual (2006). Asymmetries in bid and ask responses to innovations in the trading process. Empirical Economics 30, 913-946.

Evans, M. D. and R. K. Lyons (2002). Time-varying liquidity in foreign exchange. Journal of Monetary Economics 49 (5), 1025-1051.

Ferreira, A., M. Moore, and S. Mukherjee (2019). Expectation errors in the foreign exchange market. Journal of International Money and Finance 95, 44-51.

Garcia, M., M. Medeiros, and F. Santos (2015). Price discovery in brazilian fx market. Brazilian Review of Econometrics 35 (1), 65-94.

Garcia, M. and F. Urban (2004). O mercado interbancário de câmbio no brasil. Texto para discussão (PUC-RIO) 509, 1-48.

Glosten, L. R. and L. E. Harris (1988). Estimating the components of the bid/ask spread. Journal of Financial Economics 21 (1), 123-142.

Glosten, L. R. and P. R. Milgrom (1985). Bid, ask and transaction prices in a specialist market with heterogeneously informed traders. Journal of Financial Economics 14 (1), 71-100.

Gonzalo, J. and C. Granger (1995). Estimation of common long-memory components in cointegrated systems. Journal of Business \& Economic Statistics 13 (1), 27-35. 
Goodhart, C., T. Ito, and R. Payne (1996, January). One Day in June 1993: A Study of the Working of the Reuters 2000-2 Electronic Foreign Exchange Trading System, pp. 107-182. University of Chicago Press.

Harris, F. H. B., T. H. McInish, and R. A. Wood (2002). Security price adjustment across exchanges: an investigation of common factor components for dow stocks. Journal of Financial Markets 5 (3), 277-308.

Hasbrouck, J. (1991). Measuring the information content of stock trades. The Journal of Finance 46(1), 179-207.

Hasbrouck, J. (1995). One security, many markets: Determining the contributions to price discovery. The Journal of Finance 50 (4), 1175-1199.

Hasbrouck, J. (1999). The dynamics of discrete bid and ask quotes. The Journal of Finance 54 (6), 2109-2142.

Hasbrouck, J. (2003). Intraday prie formation in u.s. equity index markets. The Journal of Finance 58 (6), 2375-2399.

Hasbrouck, J. and R. M. Levich (2019). Fx liquidity and market metrics: New results using cls bank settlement data. Available at SSRN.

Huang, R. D. and H. R. Stoll (1997). The components of the bid-ask spread: A general approach. The Review of Financial Studies 10 (4), 995-1034.

Jang, H. and P. C. Venkatesh (1991). Consistency between predicted and actual bid-ask quote-revisions. The Journal of Finance 46 (1), 433-446.

Janot, M. M. and L. P. Macedo (2016). Efeitos das intervenções cambiais sobre a taxa de câmbio futura no brasil. Revista Brasileira de Economia 70(4), 457-480.

Kohlscheen, E. and S. C. Andrade (2013). Official interventions through derivatives: Affecting the demand for foreign exchange. Working Paper Series - Central Bank of Brazil, Research Department 317, 1-47.

Laurini, M. P., L. G. C. Furlani, and M. S. Portugal (2008). Empirical market microstructure: An analysis of the brl/us\$ exchange rate market. Emerging Markets Review 9(4), 247-265.

Lin, J.-C., G. C. Sanger, and G. G. Booth (1995). Trade size and components of the bid-ask spread. The Review of Financial Studies 8 (4), 1153-1183. 
Madhavan, A., M. Richardson, and M. Roomans (1997). Why do security prices change? a transaction-level analysis of nyse stocks. The Review of Financial Studies 10 (4), 1035-1064.

Mancini, L., A. Ranaldo, and J. Wrampelmeyer (2013). Liquidity in the foreign exchange market: Measurement, commonality, and risk premiums. The Journal of Finance 68 (5), $1805-1841$.

Nakashima, P. M. F. (2012). Análise empírica das intervenções cambias do banco central do brasil usando dados de alta frequência.

Naranjo, A. and M. Nimalendran (2000). Government intervention and adverse selection costs in foreign exchange markets. The Review of Financial Studies 13 (2), 453-477.

Pascual, R. and B. Pascual-Fuster (2014). The relative contribution of ask and bid quotes to price discovery. Journal of Financial Markets 20, 129-150.

Pasquariello, P. (2007). Informative trading or just costly noise? an analysis of central bank interventions. Journal of Financial Markets 10 (2), 107-143.

Payne, R. and P. Vitale (2003). A transaction level study of the effects of central bank intervention on exchange rates. Journal of International Economics 61 (2), 331-352.

Rime, D. (2003). New electronic trading systems in foreign exchange markets. New Economy Handbook - Academic Press, 469-504.

Roll, R. (1984). A simple implicit measure of the effective bid-ask spread in an efficient market. The Journal of Finance 39 (4), 1127-1139.

Santos, F. L. (2021). Comparing the impact of discretionary and pre-announced central bank interventions. Journal of International Money and Finance 110, 102307.

Stoll, H. R. (1989). Inferring the components of the bid-ask spread: Theory and empirical tests. The Journal of Finance 44 (1), 115-134.

Ventura, A. and M. Garcia (2012). Mercados futuro e à vista de câmbio no brasil: o rabo abana o cachorro. Revista Brasileira de Economia 66 (1), 21-48.

Yan, B. and E. Zivot (2010). A structural analysis of price discovery measures. Journal of Financial Markets 13 (1), 1-19. 